\title{
Bioengineering Approaches for Corneal Regenerative Medicine
}

\author{
S. Sharareh Mahdavi ${ }^{1} \cdot$ Mohammad J. Abdekhodaie $^{1}$ (D) Shohreh Mashayekhan ${ }^{1} \cdot$ \\ Alireza Baradaran-Rafii ${ }^{2} \cdot$ Ali R. Djalilian ${ }^{3}$
}

Received: 22 January 2020/Accepted: 6 April 2020/Published online: 21 July 2020

(c) The Korean Tissue Engineering and Regenerative Medicine Society 2020

\begin{abstract}
BACKGROUND: Since the cornea is responsible for transmitting and focusing light into the eye, injury or pathology affecting any layer of the cornea can cause a detrimental effect on visual acuity. Aging is also a reason for corneal degeneration. Depending on the level of the injury, conservative therapies and donor tissue transplantation are the most common treatments for corneal diseases. Not only is there a lack of donor tissue and risk of infection/rejection, but the inherent ability of corneal cells and layers to regenerate has led to research in regenerative approaches and treatments.

METHODS: In this review, we first discussed the anatomy of the cornea and the required properties for reconstructing layers of the cornea. Regenerative approaches are divided into two main categories; using direct cell/growth factor delivery or using scaffold-based cell delivery. It is expected delivered cells migrate and integrate into the host tissue and restore its structure and function to restore vision. Growth factor delivery also has shown promising results for corneal surface regeneration. Scaffold-based approaches are categorized based on the type of scaffold, since it has a significant impact on the efficiency of regeneration, into the hydrogel and non-hydrogel based scaffolds. Various types of cells, biomaterials, and techniques are well covered.

RESULTS: The most important characteristics to be considered for biomaterials in corneal regeneration are suitable mechanical properties, biocompatibility, biodegradability, and transparency. Moreover, a curved shape structure and spatial arrangement of the fibrils have been shown to mimic the corneal extracellular matrix for cells and enhance cell differentiation. CONCLUSION: Tissue engineering and regenerative medicine approaches showed to have promising outcomes for corneal regeneration. However, besides proper mechanical and optical properties, other factors such as appropriate sterilization method, storage, shelf life and etc. should be taken into account in order to develop an engineered cornea for clinical trials.
\end{abstract}

Keywords Corneal regeneration · Cell delivery $\cdot$ Regenerative medicine $\cdot$ Growth factor $\cdot$ Bioengineered scaffolds

Electronic supplementary material The online version of this article (https://doi.org/10.1007/s13770-020-00262-8) contains supplementary material, which is available to authorized users.

Mohammad J. Abdekhodaie

abdmj@sharif.edu

1 Department of Chemical and Petroleum Engineering, Sharif

University of Technology, 1393 Azadi Ave.,

Tehran 11365-11155, Iran

2 Ophthalmic Research Center, Shahid Beheshti University of Medical Sciences, SBUMS, Arabi Ave, Daneshjoo Blvd, Velenjak, Tehran 19839-63113, Iran
3 Department of Ophthalmology and Visual Sciences, University of Illinois at Chicago, 1200 W Harrison St, Chicago, IL 60607, USA 
Fig. 1 Corneal structure and regenerative medicine approaches

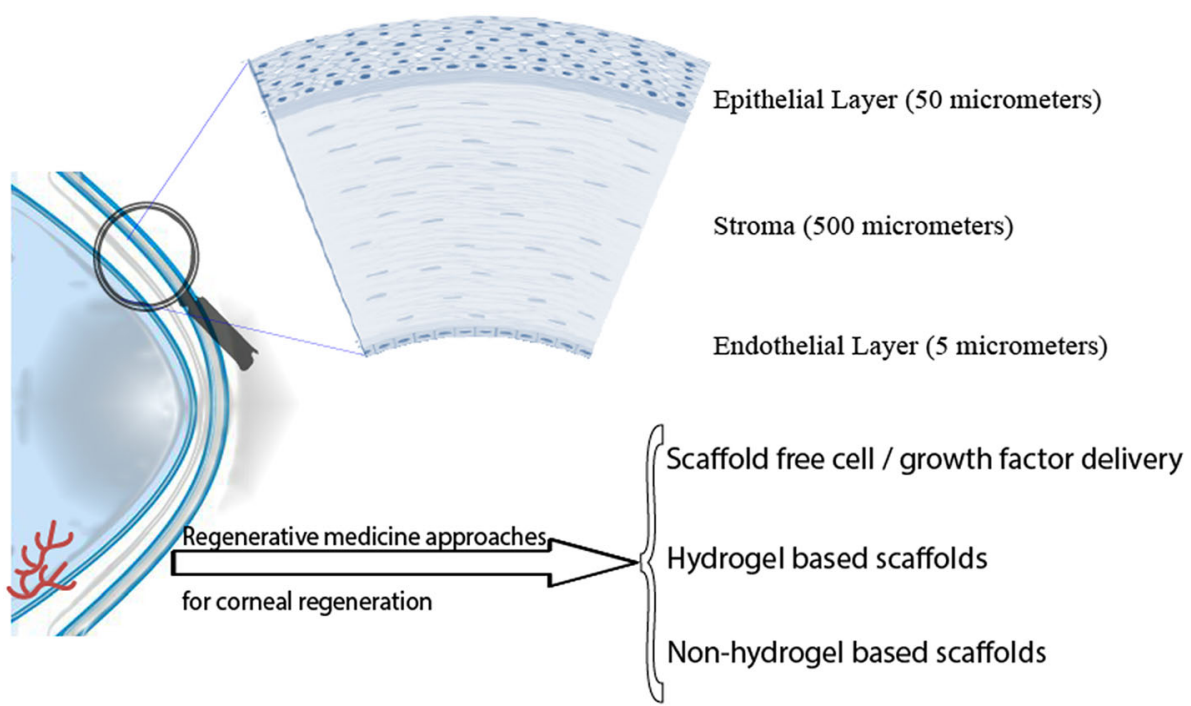

\section{Introduction}

The cornea has a complex avascular structure which consists of three main layers (the epithelium, stroma, and endothelium) (Fig. 1) and three main types of the cells (epithelial, fibroblasts/keratocytes and endothelial). Stroma makes up about $90 \%$ of the thickness of the cornea. Proteoglycans and collagen type I which are secreted by keratocytes maintain the stromal structure [1]. The healthy cornea is responsible for the transmission of about $75 \%$ of light to the lens [2] and provides an acute vision that depends on the collagen fibers and water content of its structure $[1,3]$. Besides, the uninjured cornea can preserve its transparency provided by self-renewal characteristics of the corneal epithelial layer [3, 4]. Any damage or disease results in low visual acuity, which may even lead to corneal blindness in severe conditions [5]. In 2015, 253 million people were reported to suffer from visual impairment worldwide, of which near $15 \%$ got blind [6]. Some of the prevalent corneal diseases are dry eye syndrome, keratoconus, stromal dystrophies, endothelial deficiency, stem cell deficiency, and corneal ulcers [1, 7-9]. Besides external damages, aging and genetic diseases are other reasons for corneal disorders [10]. There are many traditional treatments for healing corneal diseases such as artificial tears, contact lenses, and donor tissue transplantation $[11,12]$. However, using artificial tears is a temporary treatment [13], and frequent usage of contact lenses may evoke inflammatory responses and microbial infection [14].

Although donor tissue transplantation is the most common method for the management of severe corneal disorders, it causes rejection in many cases which may require permanent use of immunosuppression. The shortage of donor tissue is also another issue [4, 13]. Generally, the endothelial rejection rate occurs in about $21 \%$ of cases [15]. The rejection rate of corneal transplantation in keratoconus is reported to be $14 \%$ [15]. Furthermore, about two-thirds of the surgeries survive for just a decade [4]. So, many scientists are trying to solve these disputable problems by using regenerative medicine [16]. Regenerative medicine should support the rebuilding of new tissue from the host by providing the appropriate microenvironment, factors, cells, and/or signals [17, 18]. Different approaches for cell delivery have been used for corneal regeneration [19-21]. Factors of Extracellular matrix (ECM) secreted by the delivered or induced healthy host cells by paracrine signaling are intended to reconstruct the degenerated tissue [22]. The present review aims to overview a wide range of research in various approaches of regenerative medicine to treat corneal disorders.

\section{Overview of required properties for corneal regeneration}

Regenerative medicine is one of the recent approaches for reconstructing various layers of the cornea, starting from epithelium to stroma, and endothelium layers [23, 24]. Both epithelium and endothelium are considered thin layers which constituted about $10 \%$ and $1 \%$ of the corneal thickness respectively. The epithelium layer consists of various differentiates states of epithelial cells, but the endothelium layer has a monolayer cell structure. The corneal stroma is a thick layer that has a highly arranged structure $[1,23]$. So, based on the native structure of each layer, flat, two dimensional (2D) and/or three dimensional (3D) cell delivery techniques have been used to heal the injured tissue $[25,26]$. Some scientists used cell sheets, especially for treating ocular surface diseases as a $2 \mathrm{D}$ cell 
delivery system and eliminated any requirement of biomaterials [22, 27]. Although 2D scaffolds might provide suitable mechanical properties and fibril structure for cultured cells for epithelium and endothelium layers, they cannot mimic the intricate $3 \mathrm{D}$ structure of the stromal tissue [28]. Besides considering suitable mechanical properties and cell adhesion, proper permeability of the microenvironment to transfer nutrients and glucose into the structure is an important issue [4]. Transplantation method is another important consideration especially for healing ocular surface disorders; for instance, noninvasive delivery methods such as limbal stem cell (LSC)/growth factor injection are preferable to surgery which is known as an invasive manipulation with the soft corneal surface, and suturing can also cause inflammatory responses [29]. The approach of regenerative medicine is changing from invasive to noninvasive procedures for epithelium and endothelium layer regeneration and from 2D into 3D cell delivery methods for stromal tissue regeneration [30].

Scaffold characterizations such as stiffness, surface topology, degradation rate, and cytocompatibility have an undeniable effect on cell differentiation and growth in scaffold-based cell delivery methods [31]. Sufficient mechanical properties mimic the microenvironment of the host tissue and induce cell differentiation to the desired cell type [32]. The tensile strength of the cornea is $3.8 \mathrm{MPa}$ [33], therefore tuning the stiffness of the scaffold by either polymer/crosslinker concentration or crosslinking time, has a significant effect on cell differentiation and damaged tissue reconstruction [28]. Biodegradability of the scaffold is also a vital aspect of scaffold-based corneal regeneration. The desirable cell carrier should degrade when transported cells secrete ECM, so the produced matrix replaces the biomaterial. It is remarkable that mechanical properties and degradation are related to one another and can be controlled to heal the damaged tissue properly [34]. Moreover, the swelling ratio depends on the stiffness and hydrophilicity of the scaffold and affects the water content of the material [33]. The water content is related directly to the hydrophilicity and reversely to the mechanical strength of the carrier, and it is a vital issue for biocompatibility and cell growth [31]. The equilibrium water content of cornea is reported to be $80 \%$ [20]. Cytocompatibility of biomaterials is also a critical factor because it affects cell-cell and cell-tissue interactions significantly [32-34].

Cornea transparency is due to the regular distribution of stromal collagen fibers and their size (diameter range: 48-113 nm) [35]. So, proper surface topology and properties can enhance cell growth and differentiation $[19,31,33]$ in stromal tissue regeneration.

In this review, various methods of applying regenerative medicine for corneal repair are discussed and divided into three main methods of scaffold-free cell or growth factor delivery, hydrogel, and non-hydrogel based scaffolds. Naked cell injection is not considered in this review, except for discussing the impact of rho kinase (ROCK) inhibitors, because the main focus of this work is highlighting bioengineered techniques for corneal regeneration. In this case, applications of cell sheet $[22,36]$, ROCK inhibitor [37-39] and mini tissue delivery [40] are studied in corneal healing as scaffold-free cell delivery methods. In both hydrogel and non-hydrogel based scaffolds, biomaterials should be selected based on their ability to provide acceptable characteristics for tissue regeneration. They are divided into two main categories: natural and synthetic biomaterials; the former consists of two categories, including protein and polysaccharide-based biomaterials.

Protein-based biomaterials are originated from human and animal resources such as collagen, amniotic membrane (AM), and fibrin, while polysaccharide-based biomaterials are derived from either chitin such as chitosan [21] or algae and microbial sources such as alginate and dextran [17]. Decellularized tissue is also known as a natural biomaterial that is obtained by cell removal from the native tissue [33]. Natural biomaterials are popular in corneal regeneration because of their biocompatibility and proper cell-binding sites [17, 30, 31]. It has been shown that both natural biomaterials and decellularized tissues improve cell adhesion, viability, and differentiation [17, 18]. However, poor mechanical properties and high degradation rate are disadvantages of naturally derived biomaterials [17, 30, 33]. Synthetic biomaterials have acceptable mechanical strength, low degradation rate, and tunable geometry, which attract scientists' attention [17, 31]. Nevertheless, the lack of cell binding sites and inflammatory responses cause graft rejection [17]. Therefore, many studies have applied the combination of various biomaterials in order to regenerate the damaged cornea and some of them preferred to eliminate the need for any biomaterial for corneal regeneration.

Hydrogel-based scaffolds include crosslinked polymeric biomaterials that hold significant amounts of water in their 3D structure [41]. Other types of scaffolds that do not have hydrogel properties such as electrospun mats, cell delivery matrices, and films are categorized as non-hydrogel scaffolds.

\subsection{Corneal regeneration by scaffold-free cell or growth factor delivery}

Scaffold-free cell delivery attracts scientists because it eliminates the need for any additional biomaterial for tissue regeneration [41, 42]. Since autologous blood derivatives such as autologous serum (AS) and plasma rich in growth factors (PRGFs) have noticeable advantages such as availability, no risk of rejection and biocompatibility, they 
Table 1 Scaffold-free cell and/or growth factor delivery used for corneal regeneration

\begin{tabular}{|c|c|c|c|c|c|c|}
\hline $\begin{array}{l}\text { Delivery substances/delivered } \\
\text { factors }\end{array}$ & Advantages & Disadvantages & $\begin{array}{l}\text { Cells for in vitro } \\
\text { evaluation }\end{array}$ & Disease & $\begin{array}{l}\text { Clinical } \\
\text { status }\end{array}$ & References \\
\hline \multirow[t]{2}{*}{ PRP } & \multirow{2}{*}{$\begin{array}{l}\text { Secretion of various } \\
\text { growth factors and } \\
\text { stimulation of tissue } \\
\text { regeneration }\end{array}$} & \multirow{2}{*}{$\begin{array}{l}\text { Not } \\
\text { suitable for } \\
\text { severe } \\
\text { corneal } \\
\text { diseases }\end{array}$} & - & $\begin{array}{r}\text { Corneal } \\
\text { ulcers }\end{array}$ & Preclinical & {$[14,43]$} \\
\hline & & & $\begin{array}{l}\text { Conjunctival } \\
\text { fibroblasts and } \\
\text { corneal stromal } \\
\text { keratocytes }\end{array}$ & $\begin{array}{l}\text { Ocular } \\
\text { surface } \\
\text { disorders }\end{array}$ & Basic & {$[12]$} \\
\hline \multirow[t]{6}{*}{ Cell sheets } & \multirow[t]{6}{*}{$\begin{array}{l}\text { Elimination of extra } \\
\text { material for cell delivery }\end{array}$} & \multirow[t]{6}{*}{$\begin{array}{l}\text { Thin and hard } \\
\text { to be } \\
\text { handled }\end{array}$} & $\begin{array}{l}\text { Corneal epithelial } \\
\text { stem cells }\end{array}$ & $\begin{array}{l}\text { Limbal stem } \\
\text { cell } \\
\text { deficiency }\end{array}$ & Basic & {$[22]$} \\
\hline & & & $\begin{array}{l}\text { Oral mucosal } \\
\text { epithelial stem } \\
\text { cells }\end{array}$ & $\begin{array}{l}\text { Limbal stem } \\
\text { cell } \\
\text { deficiency }\end{array}$ & Preclinical & [46] \\
\hline & & & $\begin{array}{l}\text { Corneal endothelial } \\
\text { cells }\end{array}$ & $\begin{array}{l}\text { Corneal } \\
\text { endothelial } \\
\text { cell loss }\end{array}$ & Basic & [47] \\
\hline & & & $\begin{array}{l}\text { Corneal endothelial } \\
\text { cells }\end{array}$ & $\begin{array}{l}\text { Corneal } \\
\text { endothelial } \\
\text { cell loss }\end{array}$ & Preclinical & {$[40,48,49]$} \\
\hline & & & $\begin{array}{l}\text { Corneal endothelial } \\
\text { cells }\end{array}$ & $\begin{array}{l}\text { Corneal } \\
\text { endothelial } \\
\text { deficiency }\end{array}$ & Basic & {$[36]$} \\
\hline & & & $\begin{array}{l}\text { Corneal stromal } \\
\text { stem cells }\end{array}$ & $\begin{array}{l}\text { Corneal } \\
\text { blindness } \\
\text { and corneal } \\
\text { scars }\end{array}$ & Preclinical & {$[50]$} \\
\hline $\begin{array}{l}\text { Amniotic membrane and } \\
\text { umbilical cord serum }\end{array}$ & $\begin{array}{l}\text { Secretion of various } \\
\text { growth factors and } \\
\text { stimulation of tissue }\end{array}$ & $\begin{array}{l}\text { Not } \\
\text { suitable for } \\
\text { severe }\end{array}$ & - & $\begin{array}{l}\text { Ocular } \\
\text { chemical } \\
\text { burns }\end{array}$ & $\begin{array}{l}\text { First } \\
\text { clinical } \\
\text { trial }\end{array}$ & {$[51]$} \\
\hline PRP and hyaluronic acid & regeneration & $\begin{array}{l}\text { corneal } \\
\text { diseases }\end{array}$ & & Dry eye & $\begin{array}{l}\text { First } \\
\text { clinical } \\
\text { trial }\end{array}$ & {$[52]$} \\
\hline \multirow[t]{3}{*}{ ROCK inhibitor (Y-27632) } & \multirow[t]{3}{*}{$\begin{array}{l}\text { Elimination of extra } \\
\text { material for cell delivery }\end{array}$} & \multirow[t]{3}{*}{$\begin{array}{l}\text { Does not } \\
\text { affect cell } \\
\text { proliferation }\end{array}$} & - & $\begin{array}{l}\text { Bullous } \\
\text { keratopathy }\end{array}$ & $\begin{array}{l}\text { First } \\
\quad \text { clinical } \\
\text { trial }\end{array}$ & {$[53]$} \\
\hline & & & $\begin{array}{l}\text { Corneal endothelial } \\
\text { cells }\end{array}$ & $\begin{array}{l}\text { Corneal } \\
\text { endothelial } \\
\text { wound }\end{array}$ & Basic & {$[37]$} \\
\hline & & & & $\begin{array}{l}\text { Corneal } \\
\text { endothelial } \\
\text { dysfunction }\end{array}$ & Preclinical & {$[38]$} \\
\hline ROCK inhibitors (ripasudil) & $\begin{array}{l}\text { Elimination of extra } \\
\text { material for cell delivery }\end{array}$ & $\begin{array}{l}\text { Affect } \\
\text { intraocular } \\
\text { pressure }\end{array}$ & $\begin{array}{l}\text { Corneal endothelial } \\
\text { cells }\end{array}$ & $\begin{array}{l}\text { Corneal } \\
\text { endothelial } \\
\text { wound }\end{array}$ & Preclinical & [39] \\
\hline $\begin{array}{l}\text { Conditioned medium from } \\
\text { human uterine cervical stem } \\
\text { cells }\end{array}$ & \multirow{3}{*}{$\begin{array}{l}\text { Secretion of various } \\
\text { growth factors and } \\
\text { stimulation of tissue } \\
\text { regeneration }\end{array}$} & \multirow{3}{*}{$\begin{array}{l}\text { Not } \\
\text { suitable for } \\
\text { severe } \\
\text { corneal } \\
\text { diseases }\end{array}$} & - & $\begin{array}{l}\text { Dry eye and } \\
\text { corneal } \\
\text { wound }\end{array}$ & Preclinical & {$[54,55]$} \\
\hline $\begin{array}{l}\text { Conditioned medium from } \\
\text { induced pluripotent stem } \\
\text { cells }\end{array}$ & & & $\begin{array}{l}\text { Corneal endothelial } \\
\text { cells }\end{array}$ & $\begin{array}{l}\text { Corneal } \\
\text { endothelial } \\
\text { wound }\end{array}$ & Basic & {$[56]$} \\
\hline $\begin{array}{l}\text { Conditioned medium from } \\
\text { human bone marrow-derived } \\
\text { mesenchymal stem cells }\end{array}$ & & & & $\begin{array}{l}\text { Corneal } \\
\text { endothelial } \\
\text { dysfunction }\end{array}$ & Basic & {$[45]$} \\
\hline
\end{tabular}


have attracted lots of attention [12, 27]. Blood-derived proteins also contain various growth factors that promote tissue healing [43]. Besides blood derivatives, it has been shown that condition medium (CM) from various sources of stem cells contains an ample supply of growth factors that boost tissue regeneration [43, 44]. List of various scaffold-free cell and growth factor sources used for treating corneal diseases are summarized in Table 1.

\subsubsection{Cell delivery}

Scientists try to use cell sheets [57] because it does not require any biomaterial or suturing process [58]. Since ECM proteins on the cell sheets are adhesive, they do not require sutures to remain on the host tissue [59]. Okano et al. used thermo-sensitive polymer, poly ( $\mathrm{N}$-isopropyl acrylamide) (PIPAAm) to construct epithelial and endothelial cell sheets [22, 27, 42]. PIPAAm is slightly hydrophobic at $37{ }^{\circ} \mathrm{C}$, so cells attach to it via cell membrane proteins and spread normally at the physiological condition. It becomes hydrophilic and protein non-adhesive at temperatures lower than $32{ }^{\circ} \mathrm{C}$, so cells detach without any requirement of enzymes like trypsin (Fig. 2). They reported that $2 \mathrm{~mm} \times 2 \mathrm{~mm}$ biopsy of limbal tissue could provide epithelial cell sheets for more than 20 patients [60]. The obtained corneal epithelial cell sheet is attached to the injured tissue without any sutures, and the vision loss is recovered in a patient who suffered from Saltzman syndrome [60]. Therefore, cell sheets can be a promising method to deliver stem cells to the injured tissue without using any biomaterial [22, 36, 57]. They also reported complete ocular surface recovery in the rabbit model suffering from limbal stem cell deficiency (LSCD) and the regenerated tissue preserved its structure in the long-term period [46].

The same approach was applied for corneal endothelial layer recovery, and acceptable cell sheet attachment was observed. Although the endothelial cell sheet was a monolayer substrate, it was easily handled during surgical maneuvers. However, endothelial cells harvested from older donors have a shorter lifetime and are in short supply [61], so using cell sheets for corneal endothelial regeneration should be considered with other cell sources such as induced pluripotent stem (iPS) cells [62]. Nevertheless, a clinically approved method to differentiate these cells into endothelial cells has to be studied carefully [27]. Using thermo-responsive PNIPAAm for constructing endothelial cell sheets also regenerated the damaged endothelial layer with acceptable transparency in the rabbit model. Even though the long-term in vivo study is needed, PNIPAAm showed to be a promising thermo-responsive polymer for constructing both epithelial and endothelial cell sheets [49]. Notably, a longer culture period resulted in more Descemet membrane secretion which improved the cell sheet resistance to rupture during the surgical procedures regarding higher mechanical properties [47].

Although using cell sheets overcome disadvantages of scaffold-based materials, they are thin and hard to be handled [29]. Using multilayer cell sheets cause necrosis due to the lack of nutrition or blood supply [63].

Lack of cell source for the human corneal endothelial cell is the bottleneck in using cell therapy for corneal endothelial layer reconstruction. Shi et al. isolated endothelial mini sheets from the rabbit endothelium layer and injected it into the anterior chamber of the rabbit eye to investigate corneal endothelium regeneration. Comparing the results with single cell injection showed that healing of damaged tissue was three times faster when mini sheets were transplanted and the functionality of regenerated endothelium was also reported in those rabbit models, which might be contributed to their higher adhered cell density [40]. Studies with endothelial cells need a suitable animal model, as rabbits have a proliferative, mitotic endothelial cell layer that may not replicate the human corneal endothelium. The effect of ROCK inhibitor, Y-27632, on corneal endothelium regeneration was studied
A

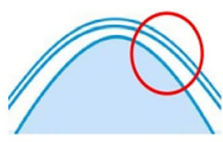

Biopsy of cornea cells

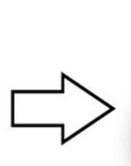

At $37^{\circ} \mathrm{C}$ cells

attach to temperature

responsive dishes

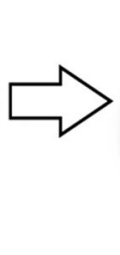

\section{Cells detach at lower temperature} as a cell sheet

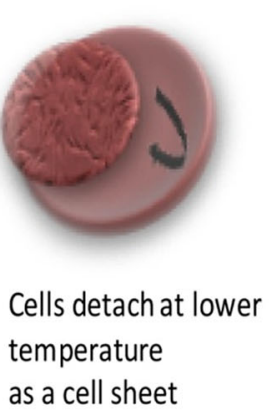

B Preoperative Postoperative

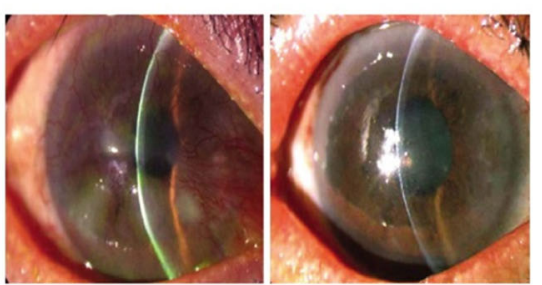

Fig. 2 A Schematic of constructing cell sheets using thermo-sensitive polymer. B Corneal healing in a patient with Saltzman syndrome before and after transplantation of corneal epithelial cell sheets. Adapted from [60] licensed under creative commons license 
in primate preclinical models. Endothelial dysfunction was developed by removing the endothelial layer from the Descemet's membrane. Both monkey corneal endothelial cells (MCECs) and Human corneal endothelial cells (HCECs) were injected with and without ROCK inhibitor into the anterior chamber of monkeys. The rejection was detected in some of the corneas received HCECs due to the xeno-transplantation. Hazy corneas were observed in all cases which were treated without ROCK inhibitor even after a year. Corneal thickness was thinner in eyes treated with ROCK inhibitor. Therefore, the ROCK inhibitor enhanced regeneration efficiency and could be applied for clinical studies [38]. It was reported that ROCK inhibitor, Y-27632, might not affect HCEC proliferation; however, it improved cell adhesion and migration which has made it a potential regenerative alternative for treating damaged corneal endothelium [37]. HCECs were injected with a ROCK inhibitor, Y-27632, into the anterior chamber of 11 patients suffering from bullous keratopathy. The mean corneal thickness was reported to be $549 \mu \mathrm{m}$ and visual acuity was achieved in 9 treated eyes. Intraocular pressure was maintained within the normal range in all cases even after 2 years and all the corneas remained transparent during this time [53]. Besides the Y-27632 ROCK inhibitor, the influence of ripasudil ROCK inhibitor on HCECs proliferation was studied with 5-ethynyl-2'-deoxyuridine (EdU) and Ki-67 staining after $48 \mathrm{~h}$. It was reported that ripasudil remarkably improved cell proliferation, so corneal endothelial wound healing was investigated in rabbit models using topical ripasudil eye drops. The corneal endothelial wound was created by corneal freezing and mechanical scraping and wound healing was evaluated in both models. In the eyes damaged by the first method, corneal endothelial regeneration was observed after $48 \mathrm{~h}$ and less haze was reported in comparison with non-treated eyes. Mechanically scrapped corneas treated with ripasudil eye drops became transparent after 2 weeks without any reported corneal edema [39].

\subsubsection{Growth factor delivery}

Growth factors promote cell proliferation, adhesion, activity, differentiation, and subsequently enhance tissue regeneration $[64,65]$. Because of its rich content of growth factors, platelet-rich plasma (PRP) can aid wound healing and repair of injured tissues to regain function (Fig. 3A). In addition, epidermal growth factor (EGF), fibroblast growth factor (FGF) and fibronectin have been shown to be effective on epithelial cells [14] migration and regeneration. Therefore, Tartara et al. treated acute corneal ulcers in rabbit models by a single PRP drop on the first and third days of observation. Their approach eliminates invasive procedures with minimum cost and time [14].

Alio et al. [66] investigated many clinical functions of the PRP in invasive and non-invasive treatments. PRP droplets also had a successful clinical outcome for treating dry eye and post-treating corneal surface after laser therapy. Moreover, solid PRP clot and combination of it with other biomaterials such as AM and bovine pericardium membrane had a promising outcome for healing corneal perforation [66]. It has been shown that PRP and fibrin membrane are a successful composition for wound closure in patients with perforated ocular ulcers. In this study, a coagulated PRP was applied to the injured cornea and covered by the autologous fibrin membrane. Only $0.3 \%$ of the patients had fibrin membrane residuals beneath the regenerated tissue and all of them recovered from corneal perforation. They reported time-consuming preparation of fibrin and PRP as the only disadvantage of their method [67]. Orive et al. compared AS and PRGF eye drop for treating ocular surface disorders. PRGF caused higher cell proliferation and migration than AS regarding its enriched content of various growth factors, especially EGF.
A
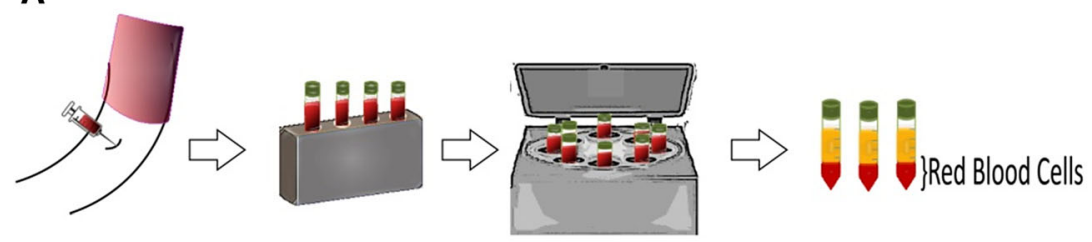
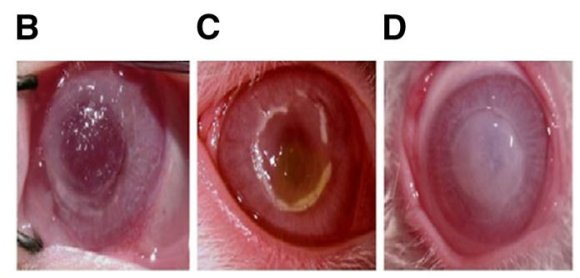

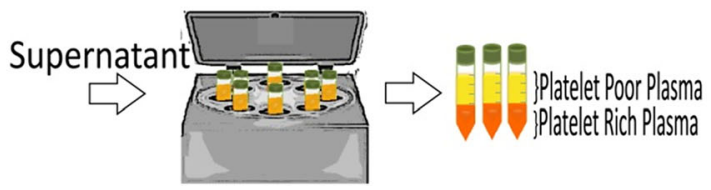

Fig. 3 A Schematic of PRP derivation. B Photographs of corneal flap attachment to the stroma immediately after the lamellar anterior keratoplasty in rabbit models. C Solidified PRP after $10 \mathrm{~min}$.
D Cornea appearance after $6 \mathrm{~h}$. Adapted with permission from [43]. (C) 2009 Springer Nature. All rights reserved 
Although PRGF had more amount of vascular endothelial growth factor (VEGF) than AS, it did not induce any vascularization which might be due to the high population of anti-angiogenic proteins in PRGF that prevented the functioning of VEGF. However, the presence of various growth factors should be controlled carefully to prevent any post-surgical side effects [12].

Besides the clinical treatment of PRP, it has been used as a substitute for suturing since sutures can trigger the inflammatory immune response and therefore require immunosuppression. The corneal flap was soaked in PRP and eventually replaced on the stroma in rabbit models after anterior lamellar keratoplasty (ALK). The tissue remained on the corneal surface without any ocular inflammation and resulted in a clear and transparent cornea without reported toxic effect (Fig. 3B-D) [43]. Transcutaneously injection of the PRP and hyaluronic acid (HA) was compared with the injection of HA alone into the lacrimal gland of patients with severe dry eye. It was suggested that PRP improved patients' symptoms significantly. It was also reported that the tear volume was increased after the injection of PRP [52]. Acceleration and improvement of tissue regeneration are caused by growth factors released from the platelets [67].

In addition to blood derivatives biomaterials, it is demonstrated that the AM also contains miscellaneous growth factors, and has anti-vascular/anti-inflammatory characteristics [68]. Sharma et al. compared conventional medical therapy with AM transplantation and topical umbilical cord serum drop, each method was tested on 15 patients with ocular chemical burns individually and controlled for 3 months. Patients who received AM transplantation and umbilical cord serum drops had significant improvement compared to the patients treated with conventional medicine. Moreover, umbilical cord serum drop was superior in terms of rapid restoration of visual acuity and pain reduction caused by prompt re-epithelialization due to its enriched content of growth factors [51]. Furthermore, topical use of conditioned medium from human uterine cervical stem cells (CM-hUCES) was shown to have effective impacts on treating dry eye and corneal wound in rabbit models. It was observed that tissue inhibitor of metalloproteinase-1 and -2 (TIMP) which were abundant in CM-hUCESC enhanced regeneration by increasing corneal epithelial cell proliferation and avoiding apoptosis [54]. Besides wound healing, CM-hUCESs were observed to have anti-inflammatory and antibacterial effects which made it a good candidate for the contact lens solution to avoid any infection [55]. Growth factor delivery was also applied for endothelium layer regeneration to enrich the cell population [69]. The proliferation efficiency of bovine corneal endothelial cells was improved by using $25 \% \mathrm{CM}$ from iPSCs instead of corneal endothelial medium (CEM). The expression of specific markers of corneal endothelial cells was higher when they were cultured in iPSC-CM in comparison with cells cultured using CEM [56]. CM from human bone marrow-derived mesenchymal stem cells (MSCs) (MSC-CM) also increased HCECs proliferation rate and gene expression [45].

\subsection{Corneal regeneration using scaffold-based tissue engineering approaches}

\subsubsection{Corneal regeneration using synthetic biomaterials}

Synthetic biomaterials have quick polymerization, tunable morphology, proper mechanical and degradation properties, and therefore, they have been used in scaffold fabrication for tissue repair [69-72]. Considering the disadvantages of natural biomaterials such as poor mechanical strength, and high degradation rate [31], synthetic polymers appealed scientists for the regeneration of injured corneal tissue. The engineering approaches applied to synthetic materials for treating various corneal diseases are categorized as non-hydrogel and hydrogel-based scaffolds. Hydrogels are widely used in tissue regeneration because of their high water content, three-dimensional structure, adjustable properties, and ample mass transfer. Nevertheless, the higher mechanical strength of non-hydrogel based scaffolds made them a favorable choice in regenerative medicine. List of various synthetic biomaterials and cell sources used for treating corneal diseases are summarized in Table 2.

2.2.1.1 Non-hydrogel-based scaffolds The high mechanical strength of non-hydrogel based scaffolds has made them an attractive option in tissue regeneration. Besides stiffness and mechanical properties, surface topography is an important factor that improves cell proliferation, growth, and differentiation, which can be tuned based on the structure of the injured tissue. For instance, since stroma has a nanofibrous structure, the electrospinning technique is one of the best methods that can mimic the corneal stromal microenvironment [94] (Fig. 4A). Wagner et al. compared solvent casting and electrospinning methods and used poly (ester urethane) urea (PEUU) as a biomaterial to carry human corneal stromal stem cells (hCSSCs) for corneal repair. HCSSCs cultured on the aligned nanofibers elongated in the direction of the nanofibers while hCSSCs cultured on the random nanofibers randomly distributed on the scaffolds. Moreover, hCSSCs cultured on the aligned nanofibers showed similar gene expression to keratocytes in comparison with those cultured either on the random electrospun nanofibers or scaffold made by solvent casting [81]. 
Table 2 Various synthetic biomaterials and cell sources used for corneal regeneration

\begin{tabular}{|c|c|c|c|c|c|c|}
\hline Biomaterial & Advantages & Disadvantages & $\begin{array}{l}\text { Cells for } \\
\text { in vitro } \\
\text { evaluation }\end{array}$ & Disease & $\begin{array}{l}\text { Clinical } \\
\text { status }\end{array}$ & References \\
\hline PEG & $\begin{array}{l}\text { Biocompatible, proper } \\
\text { mechanical properties }\end{array}$ & $\begin{array}{l}\text { Lack of cell } \\
\text { integration }\end{array}$ & $\begin{array}{l}\text { Corneal } \\
\text { endothelial } \\
\text { cells }\end{array}$ & $\begin{array}{l}\text { Loss of corneal } \\
\text { endothelial cells }\end{array}$ & Preclinical & [73] \\
\hline PEGDA & $\begin{array}{l}\text { Biocompatible, proper } \\
\text { mechanical properties }\end{array}$ & $\begin{array}{l}\text { Lack of cell } \\
\text { integration }\end{array}$ & $\begin{array}{l}\text { Limbal stem } \\
\text { cells }\end{array}$ & Corneal wound & Basic & [74] \\
\hline PEG + PAA & $\begin{array}{l}\text { Biocompatible, proper } \\
\text { mechanical properties }\end{array}$ & $\begin{array}{l}\text { Inducing } \\
\text { inflammatory } \\
\text { responses }\end{array}$ & - & $\begin{array}{l}\text { Epithelial defect } \\
\text { and corneal } \\
\text { thinning }\end{array}$ & Preclinical & {$[75]$} \\
\hline \multirow[t]{3}{*}{ PCL } & \multirow[t]{3}{*}{$\begin{array}{l}\text { Biocompatible, proper } \\
\text { mechanical properties }\end{array}$} & \multirow[t]{3}{*}{$\begin{array}{l}\text { Low degradation } \\
\text { rate }\end{array}$} & $\begin{array}{l}\text { Limbal } \\
\text { epithelial } \\
\text { cells }\end{array}$ & $\begin{array}{l}\text { Dysfunction or } \\
\text { loss of } \\
\text { epithelial stem } \\
\text { cell }\end{array}$ & Basic & [76] \\
\hline & & & $\begin{array}{l}\text { Limbal } \\
\text { epithelial } \\
\text { cells }\end{array}$ & $\begin{array}{l}\text { Limbal stem cell } \\
\text { deficiency }\end{array}$ & Basic & [77] \\
\hline & & & $\begin{array}{l}\text { Corneal } \\
\text { endothelial } \\
\text { cells }\end{array}$ & $\begin{array}{l}\text { Corneal } \\
\text { endothelial cell } \\
\text { loss }\end{array}$ & Basic & [78] \\
\hline PCL + PGS & $\begin{array}{l}\text { Biocompatible, proper } \\
\text { mechanical properties }\end{array}$ & $\begin{array}{l}\text { Low degradation } \\
\text { rate }\end{array}$ & - & Corneal blindness & Basic & [79] \\
\hline PVA & $\begin{array}{l}\text { Biocompatible, proper } \\
\text { mechanical properties }\end{array}$ & $\begin{array}{l}\text { Low degradation } \\
\text { rate, lack of cell } \\
\text { integration }\end{array}$ & - & Corneal blindness & $\begin{array}{l}\text { Preclinical } \\
\text { Basic }\end{array}$ & $\begin{array}{l}{[7]} \\
{[80]}\end{array}$ \\
\hline \multirow[t]{2}{*}{$\begin{array}{l}\text { The poly(ester urethane) } \\
\text { urea (PEUU) }\end{array}$} & \multirow[t]{2}{*}{$\begin{array}{l}\text { Biocompatible, tunable } \\
\text { physical properties }\end{array}$} & \multirow[t]{2}{*}{$\begin{array}{l}\text { Low mechanical } \\
\text { properties }\end{array}$} & $\begin{array}{l}\text { Corneal } \\
\text { stromal } \\
\text { stem cells }\end{array}$ & $\begin{array}{l}\text { Corneal } \\
\text { infections }\end{array}$ & Basic & [81] \\
\hline & & & $\begin{array}{l}\text { Corneal } \\
\text { stromal } \\
\text { stem cells }\end{array}$ & Corneal blindness & Basic & [82] \\
\hline \multirow[t]{3}{*}{ PLGA } & \multirow[t]{3}{*}{ Proper mechanical properties } & \multirow[t]{3}{*}{$\begin{array}{l}\text { Lack of cell } \\
\text { integration }\end{array}$} & $\begin{array}{l}\text { Limbal stem } \\
\text { cells }\end{array}$ & $\begin{array}{l}\text { Limbal stem cell } \\
\text { deficiency }\end{array}$ & Basic & {$[83,84]$} \\
\hline & & & $\begin{array}{l}\text { Limbal } \\
\text { epithelial } \\
\text { cells }\end{array}$ & $\begin{array}{l}\text { Limbal stem cell } \\
\text { deficiency }\end{array}$ & Basic & [85] \\
\hline & & & $\begin{array}{l}\text { Human } \\
\text { corneal } \\
\text { endothelial } \\
\text { cells }\end{array}$ & $\begin{array}{l}\text { Corneal } \\
\text { endothelial cell } \\
\text { loss }\end{array}$ & Basic & [78] \\
\hline PMMA & Proper mechanical properties & $\begin{array}{l}\text { Lack of cell } \\
\text { integration }\end{array}$ & $\begin{array}{l}\text { Human } \\
\text { corneal } \\
\text { endothelial } \\
\text { cells }\end{array}$ & $\begin{array}{l}\text { Corneal } \\
\text { endothelial cell } \\
\text { loss }\end{array}$ & Basic & [78] \\
\hline $\begin{array}{l}\text { Poly (3- } \\
\text { hydroxybutyrate-co-3- } \\
\text { hydroxyvalerate) } \\
\text { (PHBV) }\end{array}$ & Biocompatible, biodegradable & $\begin{array}{l}\text { Low mechanical } \\
\text { properties }\end{array}$ & $\begin{array}{l}\text { Limbal stem } \\
\text { cells }\end{array}$ & $\begin{array}{l}\text { Limbal stem cell } \\
\text { deficiency }\end{array}$ & Basic & {$[86]$} \\
\hline PLLA & Biocompatible, biodegradable & Low transparency & Keratocytes & $\begin{array}{l}\text { Ocular surface } \\
\text { diseases }\end{array}$ & Basic & [87] \\
\hline
\end{tabular}


Table 2 continued

\begin{tabular}{|c|c|c|c|c|c|c|}
\hline Biomaterial & Advantages & Disadvantages & $\begin{array}{l}\text { Cells for } \\
\text { in vitro } \\
\text { evaluation }\end{array}$ & Disease & $\begin{array}{l}\text { Clinical } \\
\text { status }\end{array}$ & References \\
\hline \multirow[t]{4}{*}{ Contact lenses } & \multirow[t]{4}{*}{$\begin{array}{l}\text { Elimination of extra material } \\
\text { for cell delivery }\end{array}$} & \multirow[t]{4}{*}{$\begin{array}{l}\text { Initiate corneal } \\
\text { scars }\end{array}$} & $\begin{array}{l}\text { Corneal } \\
\text { epithelial } \\
\text { cells }\end{array}$ & $\begin{array}{l}\text { Corneal surface } \\
\text { disorders }\end{array}$ & Basic & [88] \\
\hline & & & $\begin{array}{l}\text { Limbal } \\
\text { epithelial } \\
\text { cells }\end{array}$ & $\begin{array}{l}\text { Corneal surface } \\
\text { disorders }\end{array}$ & $\begin{array}{l}\text { First } \\
\quad \text { clinical } \\
\text { trial }\end{array}$ & [89] \\
\hline & & & $\begin{array}{l}\text { Limbal } \\
\text { epithelial } \\
\text { cells }\end{array}$ & $\begin{array}{l}\text { Limbal stem cell } \\
\text { deficiency }\end{array}$ & $\begin{array}{l}\text { First } \\
\text { clinical } \\
\text { trial }\end{array}$ & {$[90]$} \\
\hline & & & $\begin{array}{r}\text { Dental pulp } \\
\text { stem cells }\end{array}$ & $\begin{array}{l}\text { Limbal stem cell } \\
\text { deficiency }\end{array}$ & Basic & [91] \\
\hline \multirow[t]{2}{*}{$\begin{array}{l}\text { Autologous serum eye } \\
\text { drops and silicone } \\
\text { lenses }\end{array}$} & \multirow[t]{2}{*}{$\begin{array}{l}\text { Secretion of various growth } \\
\text { factors and stimulation of } \\
\text { tissue regeneration }\end{array}$} & \multirow[t]{2}{*}{$\begin{array}{l}\text { Not suitable for } \\
\text { severe corneal } \\
\text { diseases }\end{array}$} & - & $\begin{array}{l}\text { Persistent } \\
\text { epithelial } \\
\text { defects }\end{array}$ & $\begin{array}{l}\text { First } \\
\text { clinical } \\
\text { trial }\end{array}$ & [92] \\
\hline & & & $\begin{array}{l}\text { Limbal stem } \\
\text { cells }\end{array}$ & $\begin{array}{l}\text { Limbal stem cell } \\
\text { deficiency }\end{array}$ & Basic & [93] \\
\hline
\end{tabular}

It is demonstrated that adding the combination of fibroblast growth factor-2 (FGF-2) and transforming growth factor-beta 3 (TGF- $\beta 3$ ) to the keratocyte differentiation medium (KDM) induced hCSSCs cultured on highly aligned PEUU nanofibers to secrete collagen fibrils and corneal stromal markers. Although utilizing FGF-2 and TGF- $\beta 3$ individually, induced hCSSCs to secrete collagen in one and two directions respectively, the combination of both growth factors resulted in collagen secretion in orthogonal orientation. HCSSCs which were cultured with KDM containing TGF- $\beta 3$ growth factor, secreted smaller collagen fibers $(37 \mathrm{~nm})$ while the presence of FGF-2 in the $\mathrm{KDM}$, led to the larger collagen fibers (48 nm). HCSSCsecreted collagen under treatment with the KDM, which was supplemented with both growth factors, had the average fibril width of collagen nanofibers that would be produced by adding each growth factor individually [82]. Salehi et al. used the combination of poly (glycerol sebacate) (PGS) and polycaprolactone (PCL) to produce unidirectional nanofibers and achieved similar physical properties of the corneal stromal tissue. However, in vitro

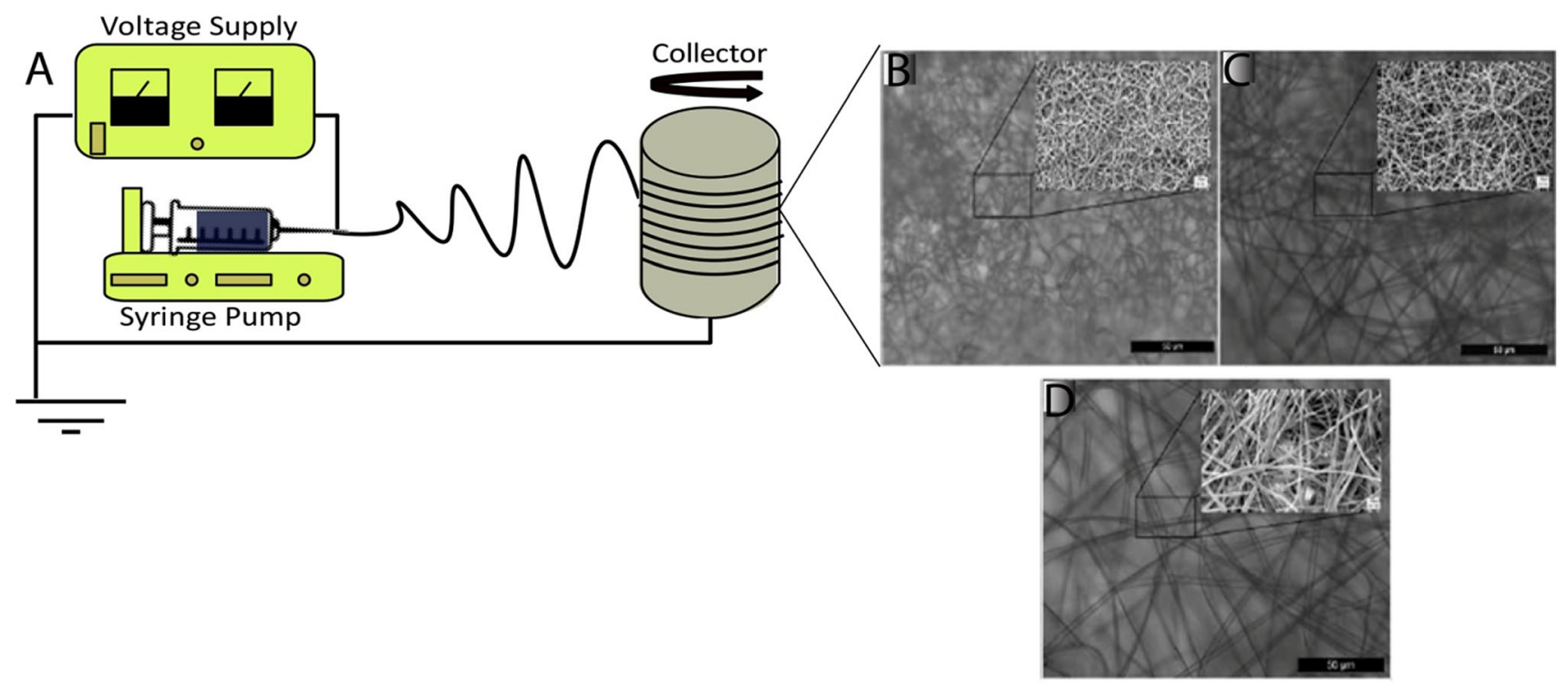

Fig. 4 A Schematic of electrospinning system. SEM of the electrospun mats made from B PCL, C PLGA and D PMMA. Adapted with permission from [78]. (C) 2018 Taylor \& Francis. All rights reserved 
assessments are required to investigate the cytocompatibility of the PGS/PCL blend [79].

This technique has also been used to produce suitable substituted for AM in corneal epithelium regeneration because of the sheet-like structure of the electrospun scaffold [76, 95]. Tandon et al. examined electrospun PCL as a synthetic carrier for limbal epithelial cells. They achieved nanofibers with a diameter of $132 \mathrm{~nm}$ and an average porosity of $85 \%$. Despite opacity of dry scaffold, wet PCL showed approximate transparency, which was less than the wet AM though. Additionally, limbal epithelial cells had $96 \%$ cell viability on PCL nanofibers [76]. Baradaran et al. also investigated the potential of electrospun PCL for replacing AM to carry LSCs. Cells cultured on electrospun scaffold had similar in vitro gene expression to the cells cultured on AM [77]. Electrospun poly (3-hydroxybutyrate-co-3-hydroxy valerate) (PHBV) was shown to improve LSCs' adhesion and growth. However, more in vivo experiments are required for clinical approaches [86]. The electrospun PLGA scaffold was also indicated to support corneal epithelial stem cells as a replacement of the AM for corneal surface regeneration, which can avoid presumable infectious diseases [85]. Ortega et al. combined two stereolithography and electrospinning approaches to mimic the limbus structure and produce a proper carrier for LSCs. They applied microstereolithography to produce poly (ethylene glycol) diacrylate (PEGDA) rings and then spread them on the collector to electrospun poly (lactic-co-glycolic acid) (PLGA) rings. LSCs adhered and grew on PLGA rings and induced epithelization in ex vivo rabbit corneas after a month [83, 84]. Electrospun mats have also been used for corneal endothelium regeneration. Fuest et al. compared electrospun PLC, PLGA and PMMA mats for their efficiency in endothelial cells growth and viability. PMMA mats were shown to have the largest pore size and resulted in the highest light transmittance. However, it was reported to have the lowest cell viability in comparison with the two other materials. The porosity and cell viability of PCL and PLGA mats were not reported to have remarkable differences (Fig. 4B-D). Nevertheless, the flat polygonal shape of endothelial cells was only observed in cells cultured on PLGA mats [78].

Contact lenses were reported as a promising and costeffective cell delivery substance for ocular surface regeneration since they were also used for improving the postsurgical comfort of the patients who suffered from various corneal disorders [96]. Girolamo et al. used contact lenses for LSC delivery in 16 patients who suffered from LSCD. Improvement in vision was reported within 2.5 years of observation for fifty percent of the patients [97]. Using contact lenses to deliver dental pulp stem cells (DPSCs) for treating LSCD also showed promising results. The DPSCs expressed epithelial cell markers, cytokeratin (CK) 3 and 12 , and prevented conjunctival inflammation in ex vivo human models. In vivo studies are required to prove the efficiency of DPSCs for corneal surface regeneration [91]. Furthermore, the material of the contact lens had a significant effect on enhancing cell attachment and oxygen transmission [98]. Deshpande et al. [99] reported acrylicacid contact lenses as the most effective substance for epithelial stem cell delivery. Mihranyan et al. took advantage of carboxylated cellulose nanowhiskers to enhance the mechanical properties of polyvinyl alcohol (PVA) for replacing conventional contact lenses. It was suggested that this combination could be flexible and have suitable optical properties [100]; however, constant usage of the contact lenses can cause corneal scar [101, 102].

2.2.1.2 Hydrogel-based scaffolds Molecular weight and crosslinking time of the poly (ethylene glycol) PEG-based hydrogels are tunable based on the required physical properties [103] Interpenetrating polymer network (IPN) was developed based on PEG and polyacrylic acid (PAA(using ultraviolet (UV)-initiated free radical polymerization. Collagen type I was covalently bonded with hydrogel to improve cell adhesion. The bioengineered scaffold was placed between the stromal bed and laser in situ keratomileusis (LASIK) flap in rabbit models. A $1.5 \mathrm{~mm}$ hole was created on the flap before its adhesion to check the regenerative properties of the hydrogel. The PEG/PAA IPN hydrogel induced epithelialization within 2 weeks and no signs of neovascularization or inflammation were reported. So, surface modification can enhance scaffold integration with cells [104]. The efficiency of silicone hydrogel molded as contact lenses ( $\mathrm{SH}$ ) was investigated to treat LSCD. Patients with persistent epithelial defects (PEDs) were treated by the combined application of SH and AS eye drops. The corneal epithelium was recovered after 2 weeks in all the patients without signs of neovascularization [92]. LSCs cultured on silicone hydrogel molded as contact lenses in media with $10 \%$ AS also expressed corneal specific markers and reached confluency within 2 weeks [93].

Wan et al. took advantage of the nanostructure of bacterial cellulose (BC) to improve the mechanical strength of their freeze-dried hydrogel for replacing donor corneal tissue. They showed that an increase in BC concentration reduced the light transmittance of PVA and blocked UV entrance into the scaffold. Besides optical properties, $12 \%$ $\mathrm{BC}$ content resulted in similar tensile strength to the native cornea $(3.8 \mathrm{MPa})$. The water content was $67-73 \%$ (native human cornea $78 \%$ ). Further in vitro and in vivo investigations are required to examine the efficiency of this scaffold for corneal regeneration [80]. PEG-based hydrogel film was also studied to regenerate corneal endothelium in 
sheep models. The hydrogel films were inserted into the anterior chamber of sheep corneas with Descemet's stripping endothelial keratoplasty (DESK)-like procedure. Although endothelial cell regeneration was not observed in vivo, the cells proliferated on the films and reached $100 \%$ confluency within a week. The hydrogel films had higher mechanical strength in comparison with donor corneal tissue, which was reported to have a positive impact on endothelial cells proliferation and activity [73].

\subsubsection{Corneal regeneration using naturally derived biomaterials}

Besides biodegradability and biocompatibility of natural biomaterials, their proper cell-binding sites have made them a favorable option for tissue regeneration. Allogenous tissue such as AM [51, 105] or different sources of decellularized tissues $[8,106]$ have been studied. The capability of the nanofibrous structure provided by electrospinning is investigated to stimulate corneal epithelium and stroma microenvironment [78]. Hydrogels provide a 3D structure for cells and stimulate the tissue-like environment for them [33]. A list of various natural biomaterials, cell sources, and corneal diseases are summarized in supplementary material Table S1.

\subsubsection{Non-hydrogel-based scaffolds Due to the devel-} opment of immunosuppressive drugs and lack of autologous tissue, especially in bilateral eye diseases, allogenous tissue has become an outstanding alternative for corneal regeneration [129, 139, 166]. For corneal epithelium regeneration, Lai et al. investigated the difference between both physical and biological properties of the AM crosslinked with glutaraldehyde (GTA) and 1-ethyl-3-(3dimethylaminopropyl) carbodiimide (EDC). Chemical crosslinking was proposed to improve the degradation rate of the AM after surgical transplantation. Longer crosslinking time increased collagen fibrils diameter in AM modified with both crosslinkers. GTA treated samples had less limbal epithelial cell viability, especially the ones modified for longer crosslinking time [140]. In addition to crosslinking methods, AM preparation procedures have an undeniable effect on its physical properties [139]. Cannon and colleagues showed that freeze-dried AM had more transparency in comparison with freeze-thawed samples for corneal surface reconstruction. However, the light transmittance of freeze-thawed proximal AM (1.357) was more similar to the native cornea (1.375) [139]. AM has wide clinical application because of its transparency, anti-inflammatory nature, enrichment in growth factors, and elasticity, which has an undeniable effect on LSC differentiation [126, 165]. Autologous and allogenous LSC sources were cultured on AM and transplanted to patients suffering from LSCD [178]. Even though allogenous LSC sources resulted in corneal epithelium regeneration [179], inflammatory immune response and even rejection were reported, in the long-term observation. So, autologous cell sources are more desirable [180]. AM was used as a graft for autologous limbal epithelial cell delivery in patients with chemical burns, and successful restoration of visual acuity was observed without the requirement of immunosuppression [142, 181].

For healing ocular surface disorders in patients with bilateral diseases, other sources of autologous epithelial cells were cultured on the AM, such as oral mucosal epithelial cells [136] and nasal mucosal epithelial cells [141]. Despite the beneficial effects of AM, there are some drawbacks such as infection risk, expensive preparation procedure, and ethical issues [51]. Galal et al. examined the potential of the human anterior lens capsule as a carrier for the ex vivo expansion of LSCs. They reported a 95\% cell viability and complete cell spread on the tissue [8]. As an alternative treatment for ocular surface disorders, gelatin matrices were crosslinked using EDC as a chemical crosslinker. The increment in EDC concentration from $0.5 \mathrm{mM}$ to $15 \mathrm{mM}$ in gelatin matrices was in favor of the proliferation and adherence of LSCs [168]. Gelatin nanofibers were studied in vitro as a carrier for eyelid fatderived stem cells for corneal epithelium regeneration. Stem cells cultured on aligned nanofibers expressed the corneal epithelial markers and had higher cell viability in comparison with the stem cells cultured on unaligned electrospun mats [166].

Silk protein has desirable mechanical, biological, and optical properties [182], which made it interesting in treating the corneal epithelial defect. Rosenblatt and coworkers observed similar corneal epithelial cell morphology and proliferation rate between cells cultured on AM and silk fibroin matrices. Therefore, they introduced silk fibroin as a suitable alternative for replacing AM [160]. Keratin film has also been considered for ocular surface reconstruction because of their stiffness, water insolubility, flexibility, and available sources $[155,183]$. Borrelli et al. implanted keratin film in rabbit models with corneal wound and compared the results with models treated by AM transplantation and investigated the effect of receiving topical steroids on wound healing. Keratin film implanted eyes treated with steroids showed more transparency and less neovascularization [183].

For corneal stroma regeneration, the decellularized cornea has been widely used since it preserves the orthogonal structure of the collagen fibrils and can mimic the mechanical and biological properties of the native stromal tissue [147]. It has been reported that the decellularization protocol has a crucial rule in the transparency of the acellular tissue [144]. Detergents are cytotoxic and 
result in degradation and opacity of the treated cornea. Moreover, freezing methods do not result in complete decellularization. Incubation of corneal stroma in human serum for 1 day following 1-h electrophoresis resulted in complete decellularization and preserved transparency of the tissue [106]. Cao and Zhang decellularized porcine cornea by enzymatic and salt treatment. The acellular cornea had a similar thickness and refractive index to the native tissue. They compared the regeneration potency of various transplantation techniques in rabbit models with stroma defects created by lamellar keratoplasty (LKP). $100 \mu \mathrm{m}$ of stroma layer was removed and replaced by either a thick $100 \mu \mathrm{m}$ acellular tissue and keratocyte cells drops or five thin acellular tissues between which keratocyte cells drops were added layer-by-layer. Although regeneration of the defect was detected after the observation period of 6 months in the rabbits treated by the first approach, native keratocyte cells did not migrate into the sheet and could not connect to the tissue. It is suggested that the layer-by-layer transplantation technique was more effective in healing stroma defects. However, precise examination with labeled seeded cells is vital to clarify the role of native and seeded keratocyte cells in the regeneration [147].

Decellularized human corneal stroma cultured on both sides by autologous adipose-derived adult stem cells showed acceptable recellularization in patients with severe keratoconus at 6 months follow up without reported inflammatory immune response. Although no apparent differences were observed among patients who receive decellularized tissue with or without stem cells, it was suggested that these stem cells might prevent scars in the long-term period [151]. Yang et al. took advantage of lenticules extracted during small incision lenticule extraction (SMILE) procedure for replacing donor corneal stroma tissue. Human corneal lenticules with a diameter of $6.6 \mathrm{~mm}$ and thickness of $\geq 100$ um were decellularized by enzymatic and salt treatment and then adhered together with fibrin glue. The scaffold was transplanted into rabbit models by ALK. Re-epithelization occurred within 16 days, and this delay was caused by the lack of the basement membrane [152].

Decellularized and decalcified fish scales, which are the rich source of the collagen, were shown to have acceptable transparency. The acellular fish scale was attained by detergent and enzymatic extraction process and transplanted using three different procedures of ALK, placing it in an interlamellar corneal pocket (IL), and implanting it sub-conjunctivally (SC) in rat models. After 3 weeks of observation, the first group was reported to have mild opacity and few signs of neovascularization. Some parts of anterior lamellar were melted in the second group, and the third group was observed to have local swelling. However, the inflammation was reported to differ from mild in the first group to severe in the third group. This assumed to be due to the inconsistency between the host injured tissue and fish scale geometry and stiffness [154]. Decellularized tissue has similar mechanical, optical, and structural properties, but has a risk of infection and rejection [184]. Therefore, scientists tried other biomaterials for repairing the cornea. Oyen et al. investigated the composite gelatin nanofibers and alginate hydrogel scaffold for the development of corneal stroma substitute. They improved the stiffness of alginate hydrogel with crosslinked gelatin nanofibers and reported acceptable optical and mechanical properties. However, corneal stromal cell survival and response to this composite structure should be studied before considering the developed scaffold for corneal regeneration [176]. Dry hydrogels, either 'xerogels' or 'aerogels' are also known as the porous scaffolds and mainly prepared using the freeze-drying technique [31, 41]. They have high porosity and controllable mechanical properties. Porosity allows cells and nutritious substances penetration into the scaffold [31]. Lai and colleagues used chondroitin sulfate to modify the cellular response to freeze-dried porous gelatin scaffold for corneal stromal regeneration. They showed that the scaffold with $0.25 \%$ content of chondroitin sulfate had similar biological and physical properties to the native cornea [163].

Non-hydrogel based scaffolds were also used to regenerate corneal endothelium. HCECs were transplanted into rabbits' eyes using decellularized AM as a substrate. Descemet's membrane and corneal endothelium were removed before transplantation. After 1 week of observation, acceptable cell density and morphology were reported [105]. Anterior lens capsule also showed high cell viability and proliferation rate for endothelial cell delivery $[148,149]$. The comparison between Link Cell ${ }^{\mathrm{TM}}$ collagen type I bio-membranes and human anterior lens capsules showed that although both of these substrates were able to preserve endothelial cell morphology, the former was not easy to handle for surgical purposes. However, the latter required the availability of the donor tissue [123]. Amano et al. decellularized human corneal stroma with a detergent solution in order to investigate its potential for the HCECs proliferation. Although acceptable cell viability and expression of functional pumping factors such as $\mathrm{Na}+/ \mathrm{K}+-$ ATPase were observed, further in vivo investigation is required to consider decellularized human corneal stroma as a substrate for endothelial cell delivery [146]. HCECs cultured on gelatin sheets expressed functional markers and had similar morphology as normal HCECs in vivo. Gelatin sheets were obtained using dehydrothermal crosslinking, and they had higher mechanical strength and transparency in comparison with atelocollagen [165]. 
Since HA is one of the glycosaminoglycans (GAGs) in cornea tissue and has ideal properties for cell migration [185], many groups preferred to use it as their main biomaterial for designing a proper scaffold. Lai characterized freeze-dried HA with different pre-freezing temperatures for endothelial cell delivery. They investigated the impact of high pre-freezing temperature $\left(0^{\circ} \mathrm{C}\right)$ and low prefreezing temperature $\left(-80^{\circ} \mathrm{C}\right)$ on the microstructure of the scaffold and cellular response. They used both developed scaffolds for rabbit corneal endothelial cell sheet delivery to rabbit models. The corneal endothelium was removed without damaging Descemet's membrane before the surgery. Low pre-freezing temperature caused packed structure, which had a negative effect on cellular activity and led to neovascularization in treated eyes [186].

\subsubsection{Hydrogel-based scaffolds 3D structures of} hydrogels alongside their water absorbance and cytocompatibility made them a favorable choice for scientists to reconstruct damaged corneal tissue [31]. Since HA has been shown to have a positive impact on corneal epithelial cells migration but not on cell proliferation [187], the combination of HA, collagen, and gelatin was used to improve human corneal epithelial cells proliferation. This combination was transparent when soaked into the glycerol, and it was reported that higher HA concentration led to higher mechanical strength [174]. A photo-chemical collagen-based hydrogel was shown to be a good candidate for LSC delivery. Connon et al. combined both photochemical crosslinkers, and plastic compressed collagen to improve the mechanical strength of the hydrogel. LSCs attached to the hydrogel and exhibited a polygonal structure after 5 days. Cultured LSCs differentiated into the epithelial cell, which was approved by an epithelial cell marker, CK14 [121].

In situ forming hydrogels which have all advantages of hydrogels in addition to the efficient cell or growth factor encapsulation, minimally invasive transplantation, and simple formation in the shape of the injury have become very popular in regenerative medicine approaches [188, 189]. In situ forming gels for corneal regeneration are usually liquid at low temperatures and form a gel at biological temperature. At low temperatures, the polymer mixture forms a solution due to the disintegration of polymer chains and a hydrogen bond between the hydrophilic groups of the polymer and the water molecules. As the temperature increases, the hydrophobic interactions improve and break up hydrogen bonds, which lead to hydrogel formation [190]. A thermo-sensitive solution was prepared with the combination of gelatin, chitosan, and $\beta$ glycerol phosphate (GP) for eyelid fat-derived stem cell delivery. After 3 weeks, the expression of CK 3, 18, and 19 was observed in vitro; this indicated the differentiation of encapsulated stem cells into the epithelial cells. The concentrations of gelatin and GP could be controlled due to the required gelation time [177].

The in situ approach was also employed to regenerate corneal stoma. Collagen was modified using azide and dibenzocyclooctyne (DBCO) groups to fabricate a transparent collagen-based hydrogel by strain-promoted alkyne cycloaddition crosslinking at $37^{\circ} \mathrm{C}$. For biocompatibility evaluation, the pre-polymer solution was mixed with keratocyte cells and used to fill the wound created by ALK in ex vivo rabbit corneas. A stratified epithelium was regenerated on the top of the scaffold and delivered keratocyte cells elongated within the hydrogel after 6 days. Further in vivo investigation is required to evaluate the role of delivered cells in the regeneration process and study the impact of host cells migration on the corneal repair [124].

Fibrin gel, which is regenerated from the combination of fibrinogen and thrombin, can also be formed in situ for stromal regeneration. Corneal epithelium and a thin layer of anterior stroma were removed mechanically in mouse models, and fibrinogen mixed with purified extracellular vesicles (EVs) or CSSCs was used to cover the wound. Fibrin gel was then produced by adding thrombin to the wound bed. Corneal epithelial layer was recovered over the damaged tissue after $24 \mathrm{~h}$, and corneal scarring was prevented in treated eyes after 2 weeks. It was concluded that EVs eliminated the requirement of live cells which could be safer and cheaper for clinical trials [171].

Prefabricated collagen-based hydrogels have been widely studied as a feasible corneal stromal substitute [191]. Griffith et al. copolymerized recombinant human collagen type III (RHCIII) with [poly (N-isopropylacrylamide-coacrylic acid-coacryloxysuccinimide)] (TERP]) and TERP5, which has been derived from TERP. Both hydrogels were optically clear and had higher glucose diffusion permeability than native stroma. However, epithelial cells had a higher proliferation rate on collagenTERP5 hydrogels than collagen-TERP hydrogels. They implanted collagen-TERP5 hydrogels into micro pig models using LKP after removal of host epithelium and anterior stroma. After a 6-week observation, epithelialization and stromal regeneration successfully occurred, and all of the corneas remained transparent [10]. Subsequently, they crosslinked porcine collagen type I with EDC/N-Hydroxysuccinimide (NHS) for corneal substitution to avoid the synthesis of TERP. The developed hydrogel was molded to fit corneal curvature and thickness and implanted into both rabbit and mini pig models for in vivo investigation using deep lamellar keratoplasty (DLKP). The treatment process occurred over the same period in both animals. A stratified epithelium was observed after a month, and stromal cells had migrated from the host tissue into the implant after 3 months. Six months after surgery, 
the full integration of the implant to the host cornea was achieved with no reported inflammatory responses [107, 192]. They compared the optical and mechanical properties of collagen type I and III crosslinked with EDC/ NHS for replacing the donor corneal tissue. Both scaffolds had the same refractive index, but the hydrogel composed of collagen type III had higher light transmission than the sample composed of collagen type I. Although both hydrogels had similar mechanical properties, the collagen type III based sample had a lower degradation rate. So, they introduced collagen type III as a potential candidate for donor corneal tissue replacement, whereas $70 \%$ of normal cornea comprises of collagen type I [108, 111]. Both types of hydrogels were implanted into pig models using DLKP, and post-operative assessment of nerve regeneration was conducted for a year to compare the in vivo efficiency of them. Nerve regeneration in pig models treated by hydrogels was the same as in pig models treated by donor tissue transplantation. Therefore, nerve regeneration was independent of the type of collagen, and both types of hydrogel were proper for neural regeneration in anterior stroma [120]. To improve the functionality of the collagen type III based hydrogel, they used phosphorylcholine (2-methacryloxy-ethyl phosphorylcholine) (MPC) in addition to EDC/NHS and crosslinked collagenMPC solution with chemical and photoinitiators. Light transmission of chemically cross-linked RHCIII-MPC was higher than the normal cornea while photo cross-linked RHCIII-MPC had close light transmission to the native corneal tissue; however, the latter had no backscatter. After implantation of the hydrogels in rabbits' and mini pigs' eyes using DLKP, epithelial cells covered all the implants after 1 week, and stromal cells repopulated the hydrogels after 9 months. However, collagen-MPC hydrogels showed hazy marks in both pig and rabbit cases, and the antiinflammatory drug was required to resolve neovascularization [112, 125, 129]. UV crosslinked collagen-MPC hydrogels were implanted in minipig and human models using ALK. In both cases, corneal epithelium and anterior stroma were damaged, and the healing process was followed up for 2 years. Although transplantation of this scaffold had acceptable regenerative outcomes in minipig models, only $50 \%$ of human trials were successful, and it was implied that animal models might be comparable to patients with non-severe corneal disorders [127]. Following their research, collagen type III hydrogels crosslinked with EDC/NHS were implanted into ten patients' eyes with vision loss caused by either keratoconus or corneal scars using ALK. Stromal cells migrated into the transplanted hydrogels, and epithelialization was observed in all patients after 7 months. The morphology of epithelial and stromal cells was normal, and optical acuity was modified in $40 \%$ of the cases. They represented this hydrogel as a temporary regeneration of the cornea until a donor corneal tissue or an implant becomes available [110]. This clinical study was investigated for 4 years postoperatively. They observed an acceptable integration of the implants to the host tissue, and the regenerated tissue had constant geometry after 4 years of observation. Corneal stromal cell migration was observed even after 4 years, and cell density was higher in the transplanted hydrogels than in the donor corneal tissue. So, further development of the EDC/NHS cross-linked RHCIII could make them a promising candidate for treating corneal blindness [128]. For the clinical assessment of EDC crosslinked RHCIII, ten patients of whom nine of them had advanced keratoconus, and one of them had a permanent mid stroma scar participated in the clinical trial. The scaffolds were implanted using ALK, and the healing process was observed for 2 years after the surgery. Three overlying sutures were used to hold the implant, which was reported to delay epithelization and cause haziness, despite the removal of the sutures after 1 month and a half; opacity remained in those regions even 2 years after the surgery [5]. Gelation kinetic of EDC crosslinked RHCIII was hard to control for large-scale manufacturing, so they tried another carbodiimide crosslinker, N-cyclohexyl- $\mathrm{N}^{\prime}-(2-$ morpholinoethyl) carbodiimide method-p-toluenesulfonate (CMC), which had higher gelation time and it could be handled in ambient temperature. Physical properties and in vivo performance of RHCIII crosslinked with CMC and EDC were compared to introduce the proper combination for corneal regeneration. Both hydrogels had high mechanical properties and could be handled easily for surgical procedures. Full-thickness corneal transplantation was used to implant the hydrogels into mice models. Both samples caused acute inflammatory response and rejection in the mice models. However, CMC crosslinked hydrogels had acceptable handling properties for implanting the scaffold, and the process took place in the ambient condition, which made it favorable to scale up the manufacturing process [109]. Hydroxypropyl methylcellulose (HPMC) was also shown to improve the transparency of collagen gels. Moreover, interlamellar transplantation was applied to investigate the regenerative properties of the collagen and HPMC composite in rabbit models. Keratocyte cells repopulated the hydrogels, and the clear cornea was observed after 6 months [113].

The various combinations of collagen, HA, and chitosan were studied for bioengineering the cornea. The hydrogel composed of $20 \%$ collagen, $10 \%$ chitosan, and $0.5 \% \mathrm{HA}$ had reasonable light transmittance and mechanical strength for corneal regeneration. For in vivo assessment, a stromal pocket of $0.1 \mathrm{~mm}$ thickness and $7 \mathrm{~mm}$ diameter was made with a cataract knife, and different complexes of the hydrogel were implanted into the created pocket, and the regeneration process was observed for 5 months. 
Inflammatory responses and neovascularization were disappeared after a month, and the complex which contained $20 \%$ collagen, $10 \%$ chitosan, and $0.5 \% \mathrm{HA}$ had the highest in vivo biocompatibility comparing to the mixtures with the same chitosan and HA concentration but different collagen content $(0 \%$ and $30 \%)$ [11].

Addition of collagen type I to hydrazone crosslinked HA reduced the transparency of the hydrogel but increased its mechanical strength and biocompatibility. This combination was used for human adipose stem cells (hASCs) delivery for repairing damaged corneal stromal tissue in pig models. The stromal cavity was created in the center of the cornea, and the hydrogel which contained hASCs was delivered to the injured tissue. Delivered stem cells were integrated into the cornea within 7 days, and the repopulation of epithelial cells was reported within this period. Longer preclinical observations are required to investigate the efficiency of hASCs delivery for treating corneal stromal defects [134].

Patel et al. studied the optical and mechanical properties of corneal-shaped molded collagen with three different crosslinkers, which were UV, Genipine, and EDC, for corneal stromal replacement. All collagen crosslinking methods reduced UV light transmission and increased the visible light transmission while non-cross linked hydrogel had close optical properties to the normal corneal tissue in the UV range. EDC and genipine crosslinked collagen had the highest and the lowest ultimate tensile strength, respectively [115]. Kochevar et al. utilized a green light source to crosslink collagen with rose bengal as a photoinitiator for treating keratoconus. Increased young's modulus suggested that rose bengal had formed a complex combination with collagen structure due to the opposite surface charges. Despite cytotoxicity of rose bengal, it was demonstrated that applying green light to crosslink the prepolymer solution did not have a cytotoxic effect on keratocyte cells [116].

Compressed collagen hydrogels which contained hCSSCs was reported to suppress scar formation and improve regeneration of the injured tissue in mouse models with corneal scars in the anterior stroma. Lower inflammatory immune response was detected when fibrin gel was applied instead of sutures to implant the hydrogel to the damaged stroma [133].

Bioprinting is a new developing method for mimicking proper microenvironment for encapsulated cells, especially for corneal stromal regeneration. In this technique, required geometry is converted to the biomaterial via computer [193]. It has been reported that among three common types of inkjet, extrusion-based and laser-assisted 3D printers, inkjet, and extrusion-based 3D printers are more efficient for printing corneal regenerative scaffolds. Inkjet $3 \mathrm{D}$ printers regenerate the designed geometry by deposition of droplets of the bio-ink. In an extrusion-based 3D printer, usually, the ink will be forced through a nuzzle to be printed layer by layer on the considered surface [193]. Wu and colleagues used the combination of $1 \%$ alginate, $10 \%$ gelatin and $0.82 \mathrm{mg} / \mathrm{ml}$ collagen for $3 \mathrm{D}$ printing structure of the cornea with human epithelial stem cells using the extrusion-based system (Fig. 5). They reported good mechanical and optical properties of the scaffold and observed CK3 marker after cell culture [173]. Connon et al. used alginate and collagen as a bio-ink to print corneal stromal equivalent. In vitro biocompatibility of the $3 \mathrm{D}$ bioprinted keratocyte cells was reported to be $83 \%$ after a week [194]. Campos et al. used the agarose-based prepolymer solution as a bioink to polymerize the mixture of agarose and collagen type I by lowering the temperature. They used a cell-friendly bioprinter to encapsulate primary human keratocyte cells within the hydrogel and obtain an accurate geometry of the native human cornea. Expression of keratocyte cell markers such as keratocan and lumican was detected 7 days after the 3D bioprinting process [135].

All the discussed approaches have also been employed to regenerate corneal endothelium. Two different crosslinking agents, glutaraldehyde and EDC/NHS, were compared to improve the physical, chemical, and biological properties of HA for recovery of the functional endothelial layer [157]. Anterior chamber implantation was applied to evaluate the potential of crosslinked HA disks to induce an inflammatory immune response in rabbit models. Six months after the operation, it was noticed that EDC/ NHS cross-linked hydrogels disappeared, and corneas remained clear. In contrast, GA crosslinked HA disks did not degrade completely within this period and triggered an inflammatory immune response, which led to the opacity of the eyes [195].

Yamagami et al. optimized transparent collagen sheets for corneal endothelial cell delivery. The hydrogel was implanted into the anterior chamber of rabbit corneas after the removal of Descemet's membrane to estimate the in vivo regeneration potential. A renewed functional endothelial layer was observed after a month without a sign of inflammation [122]. Amano and coworkers manipulated the porcine collagen by molding, UV irradiation, and vitrification in order to achieve suitable geometry, transparency, and stiffness for restoring the corneal endothelial layer. The modified scaffold was inserted into the anterior chamber of rabbit corneas through a thin incision and fixed to the posterior stroma by injecting air bubbles. Four months post-operative observation showed that the implanted scaffold maintained corneal transparency without inflammation, and the curvy structure enhanced the membrane attachment [130].

Although collagen has higher cytocompatibility in comparison with gelatin, the latter has attracted lots of 


\section{A}

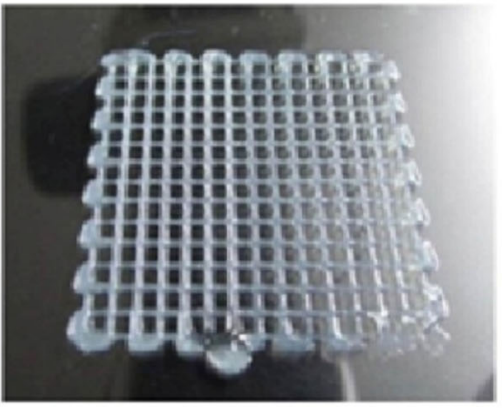

D

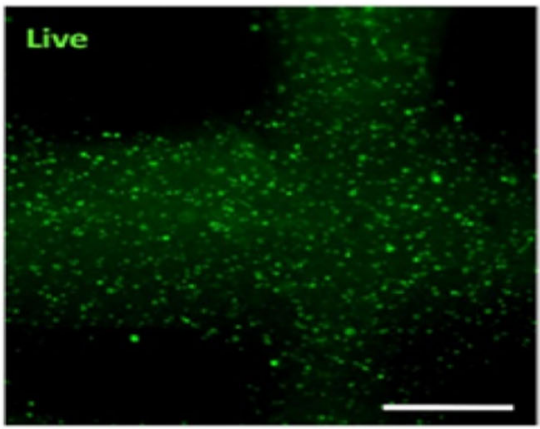

B
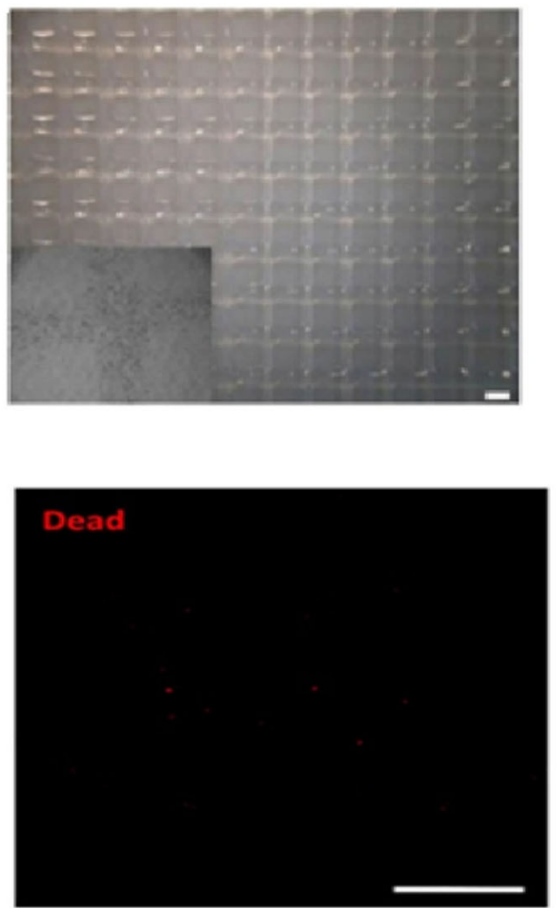

C
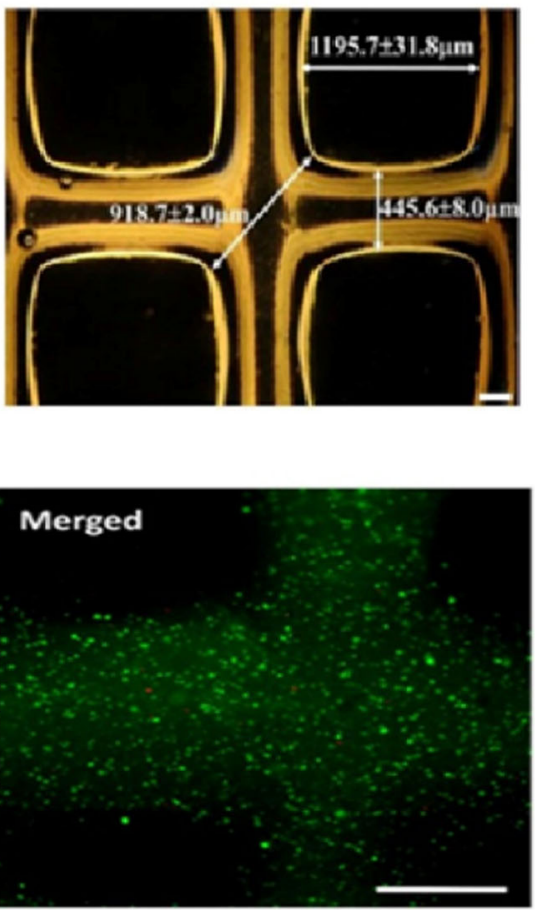

Fig. 5 A Top view of bioprinted collagen/gelatin/alginate scaffold. B, C Porous structure of the finalized scaffold including 3D HCECs/ hydrogel. The overall size images of the $3 \mathrm{D}$ constructs, including the pore size, thread diameter and max pore distance $(\mathbf{B}$ : scale bar, $1 \mathrm{~mm}$;
C: scale bar, $200 \mu \mathrm{m})$. D Cell viability after printing by live/dead staining (scale bar, $500 \mu \mathrm{m}$ ). Reprinted from [173] licensed under creative commons license

modified substrate was shown to have a significant effect on cell proliferation and viability in in vitro analysis. The hydrogel was implanted in the anterior chamber of rabbit corneas after the removal of the Descemet's membrane and endothelial layer. A clear cornea was observed after 3 weeks, and the scaffold was successfully integrated with the posterior stroma [164].

Liu et al. examined an in situ self-cross-linked hydrogel produced by the combination of modified chitosan and alginate for restoring damaged endothelium. Despite biocompatibility and cytocompatibility of both biomaterials, the former has inadequate solubility in benign solvents, and the latter has a low biodegradation rate. Therefore, they mixed a derivative of chitosan, hydroxypropyl chitosan, and oxidized sodium alginate to get a water-soluble composite with a low biodegradation rate. Rabbit corneal endothelial cells were added to the pre-polymer solution for further in vivo tests. After removal of the endothelial layer in rabbit corneas, the solution was injected into the damaged area, and a self-crosslinked hydrogel was formed after $5 \mathrm{~min}$. Although a mild inflammation was observed in the anterior chamber on day 10 , the treated corneas remained clear after a month for 8/12 rabbits without any apparent signs of neovascularization [175]. 
Table 3 Various combinations of biomaterials and cell sources used for corneal regeneration

\begin{tabular}{|c|c|c|c|c|c|c|}
\hline Biomaterial & Advantages & Disadvantages & $\begin{array}{l}\text { Cells for in vitro } \\
\text { evaluation }\end{array}$ & Disease & $\begin{array}{l}\text { Clinical } \\
\text { Status }\end{array}$ & References \\
\hline $\mathrm{PCL}+$ alginate + chitosan & $\begin{array}{l}\text { Proper } \\
\text { mechanical } \\
\text { properties }\end{array}$ & $\begin{array}{l}\text { Do not mimic the } 3 \mathrm{D} \\
\text { structure of the native } \\
\text { tissue complicated process }\end{array}$ & - & $\begin{array}{l}\text { Corneal } \\
\text { ulceration }\end{array}$ & Basic & [198] \\
\hline PCL + collagen & $\begin{array}{l}\text { Proper } \\
\text { mechanical } \\
\text { properties }\end{array}$ & $\begin{array}{l}\text { Do not mimic the 3D } \\
\text { structure of the native } \\
\text { tissue }\end{array}$ & $\begin{array}{l}\text { Rabbit corneal } \\
\text { cells }\end{array}$ & $\begin{array}{l}\text { Injured } \\
\text { corneal } \\
\text { tissue }\end{array}$ & Basic & [199] \\
\hline \multirow[t]{2}{*}{ Collagen + PVA } & Biocompatible & $\begin{array}{l}\text { Inducing inflammatory } \\
\text { responses, lack of the } \\
\text { expression of basement } \\
\text { membrane components }\end{array}$ & $\begin{array}{l}\text { Human and } \\
\text { rabbit corneal } \\
\text { epithelial stem } \\
\text { cells }\end{array}$ & $\begin{array}{l}\text { Corneal } \\
\text { disorders }\end{array}$ & Preclinical & {$[200]$} \\
\hline & & & $\begin{array}{l}\text { Human } \\
\text { keratocytes } \\
\text { and human } \\
\text { epithelium }\end{array}$ & $\begin{array}{l}\text { Corneal vision } \\
\text { loss }\end{array}$ & Basic & [201] \\
\hline $\begin{array}{l}\text { PEG- } \\
\text { DBA }+ \text { collagen }+ \text { chitosan }\end{array}$ & $\begin{array}{l}\text { Proper } \\
\text { mechanical } \\
\text { properties }\end{array}$ & $\begin{array}{l}\text { Inducing inflammatory } \\
\text { responses }\end{array}$ & $\begin{array}{l}\text { Human corneal } \\
\text { epithelial cells }\end{array}$ & $\begin{array}{l}\text { Corneal } \\
\text { disorders }\end{array}$ & Preclinical & [202] \\
\hline PEGDA + Collagen & Biocompatible & $\begin{array}{l}\text { Inducing inflammatory } \\
\text { responses }\end{array}$ & $\begin{array}{l}\text { Mesenchymal } \\
\text { stem cells }\end{array}$ & $\begin{array}{l}\text { Corneal } \\
\text { blindness }\end{array}$ & Preclinical & [203] \\
\hline $\begin{array}{l}\text { Short collagen-like peptides } \\
\text { (CLPs) + PEG }\end{array}$ & Biocompatible & High stiffness & - & $\begin{array}{l}\text { Corneal } \\
\text { blindness }\end{array}$ & Preclinical & [204] \\
\hline $\begin{array}{l}\text { Carboxylated nano-cellulose } \\
\text { whiskers (CNC) + PVA }\end{array}$ & $\begin{array}{l}\text { Biocompatible, } \\
\text { high } \\
\text { transparency }\end{array}$ & High viscoelasticity & - & $\begin{array}{l}\text { Corneal } \\
\text { degeneration }\end{array}$ & Basic & {$[100]$} \\
\hline $\mathrm{AM}+\mathrm{PVA}$ & $\begin{array}{l}\text { Biocompatible, } \\
\text { biodegradable }\end{array}$ & $\begin{array}{l}\text { Inducing inflammatory } \\
\text { responses }\end{array}$ & $\begin{array}{l}\text { Human and } \\
\text { rabbit corneal } \\
\text { epithelial stem } \\
\text { cells }\end{array}$ & $\begin{array}{l}\text { Corneal } \\
\text { disorders }\end{array}$ & Preclinical & [205] \\
\hline Chitosan + PVA & $\begin{array}{l}\text { Proper } \\
\text { mechanical } \\
\text { properties }\end{array}$ & $\begin{array}{l}\text { Low degradation rate } \\
\text { Do not mimic the } 3 \mathrm{D} \\
\text { structure of the native } \\
\text { tissue }\end{array}$ & - & $\begin{array}{l}\text { Corneal } \\
\text { blindness } \\
\text { and cataract }\end{array}$ & Basic & [206] \\
\hline Chitosan + PEG & $\begin{array}{l}\text { Proper } \\
\text { mechanical } \\
\text { properties }\end{array}$ & $\begin{array}{l}\text { Low degradation rate } \\
\text { Do not mimic the } 3 \mathrm{D} \\
\text { structure of the native } \\
\text { tissue }\end{array}$ & - & $\begin{array}{l}\text { Corneal } \\
\text { endothelial } \\
\text { dysfunction }\end{array}$ & Basic & [207] \\
\hline PEG + silk fibroin & $\begin{array}{l}\text { Proper } \\
\text { mechanical } \\
\text { properties }\end{array}$ & $\begin{array}{l}\text { Low degradation rate, Lack } \\
\text { of the expression of } \\
\text { epithelial cells markers }\end{array}$ & $\begin{array}{l}\text { Limbal stem } \\
\text { cells }\end{array}$ & $\begin{array}{l}\text { limbal stem } \\
\text { cell } \\
\text { deficiency }\end{array}$ & Preclinical & [208] \\
\hline $\begin{array}{l}\text { Silk fibroin }+ \text { polyurethane } \\
(\mathrm{PU})\end{array}$ & $\begin{array}{r}\text { Biocompatible, } \\
\text { biodegradable }\end{array}$ & Lack of cell integration & $\begin{array}{l}\text { Conjunctiva } \\
\text { derived } \\
\text { mesenchymal } \\
\text { stem cells }\end{array}$ & $\begin{array}{l}\text { Corneal } \\
\text { blindness }\end{array}$ & Basic & [209] \\
\hline $\begin{array}{l}\text { Compressed collagen }+ \text { poly } \\
\text { (lactic-co-glycolide) (PLGA) }\end{array}$ & $\begin{array}{l}\text { Biocompatible, } \\
\text { proper } \\
\text { mechanical } \\
\text { properties }\end{array}$ & Low transparency & $\begin{array}{l}\text { Human corneal } \\
\text { epithelial cells } \\
\text { and human } \\
\text { keratocytes }\end{array}$ & $\begin{array}{l}\text { Corneal } \\
\text { ulceration }\end{array}$ & Basic & {$[210]$} \\
\hline
\end{tabular}

\subsubsection{Corneal regeneration using a combination of various biomaterials}

A combination of different biomaterials has become a popular approach for corneal regeneration since each biomaterial has various properties, and a combination of them can overcome unfavorable features of each biomaterial. Natural biomaterials have been added to the synthetic biomaterials to increase cytocompatibility and 
biodegradation rate $[31,57]$. A list of combined biomaterials and selected cell sources for healing corneal diseases is presented in Table 3 .

2.2.3.1 Non-hydrogel-based scaffolds A silk fibroin membrane was modified with PEG to improve its mechanical strength. The mixture of $4 \% \mathrm{w} / \mathrm{v}$ silk fibroin and $40 \% \mathrm{w} / \mathrm{v}$ PEG was molded to get a curvature structure for LSCs delivery. This mixture gave a transparent, stiff, and suturable scaffold. A contact lens-based LSC delivery transplantation procedure was performed on rabbit corneas with LSCD to investigate the efficiency of in vivo regeneration. Despite mild vascularization, the corneal epithelial thickness was increased after 4 months, which was confirmed by a stratified epithelium that covered treated eyes [208].

Electrospinning the mixture of synthetic and natural biomaterials has been shown to boost the mechanical strength of the scaffold without adding a crosslinking agent. Mortazavi et al. generated hybrid polyurethane (PU)-silk nanofibers by using the electrospinning technique for treating corneal epithelial defects. Electrospun PU mats gave larger nanofibers diameter than electrospun silk mats and conjunctival-derived mesenchymal stem cells had better cell growth and migration on them because of the larger voids between the nanofibers. However, a highly porous interconnected network was achieved in the hybrid scaffold which led to the higher expression of epithelial cell markers [209].

Electrospinning technique has been also utilized to fabricate a proper stromal substitute. Mi et al. electrospun the mixture of collagen and PVA to improve the disadvantages of each biomaterial. It was observed that increasing PVA concentration had counter-influence on light transmittance. As it was expected, aligned nanofibers showed better optical and mechanical properties. Both human epithelial and keratocyte cells grew and adhered to the mats in vitro. The cultured cells elongated into the direction of the aligned nanofibers and covered the scaffold surface homogenously [201]. Park et al. designed an innovative system to electrospun a curved shape radially aligned 3D scaffold. The mechanical and optical properties of electrospun collagen and PCL mixture were acceptable enough to be used as a corneal substitution. They isolated all three main types of corneal cells (epithelial, stromal fibroblast, and endothelial cells) and cultured them on the constructed scaffold to evaluate its biocompatibility in vitro. Excellent cell growth, adhesion, and proliferation were observed on their fabricated scaffold [199].

The salt leaching technique was applied to get a PEGDA-based super porous scaffold as a potential for replacing donor corneal tissue. Porous PEGDA-based scaffold was soaked into the mixture of collagen type I and fibroblast cells to uptake them into the pores. It was reported that mixing both biomaterials before cell seeding would reduce cell adhesion. Although the super porous structure was useful for better cell migration and adhesion, collagen was essential for high cell viability [203].

2.2.3.2 Hydrogel-based scaffolds Although collagen is one of the best candidates for corneal regeneration, its poor water solubility and mechanical strength have always been challenging $[61,191]$. Therefore, the mixture of collagen with other biomaterials such as chitosan [11], alginate [194], PEG [202], PCL [199] and etc. can be a better option for improving scaffold stiffness. Low-temperature-crystallized PVA was shown to be transparent and has high mechanical strength. However, it is not a cell-friendly biomaterial, so it was soaked into collagen type I solution to overcome this problem. Rabbit corneal epithelial stem cells were cultured on the hybrid scaffold using the air-lift culturing method for in vivo investigation. The hydrogels were transplanted as a lamellar graft in rabbit corneas. In spite of the addition of soluble laminin, the basal cells did not secrete basement membrane elements such as collagen type IV and VII after 3 weeks. Although a stratified epithelium was observed, an inflammatory immune response had loosened the sutures and detached the epithelium from the scaffold surface after a few days. They suggested that crosslinking either a thick layer of collagen or acellular AM to the fabricated scaffold might improve cell secretion [200]. After AM immobilization, higher efficiency of rabbit corneal epithelial stem cell differentiation was reported on the modified substrate. Rabbit corneas were subjected to the same in vivo investigation to evaluate the regenerative capability of the modified scaffold. Although stratified epithelium was observed after 2 weeks, epithelial defect and inflammation were reported in transplanted eyes after a month [205].

The combination of PVA and chitosan was declared to have comparable optical transmittance and swelling ratio to the native cornea and in vitro evaluation showed $90 \%$ viability of human corneal epithelial cells. Nevertheless, more in vivo studies are required to investigate the inflammatory immune response of this mixture [206].

For stromal tissue replacement, aligned electrospun PLGA mats were sandwiched in between compressed collagen gels to improve the mechanical properties. Shengli et al. perforated the surface of electrospun mats using a laser machine to tune mechanical strength and transparency. The diameter of the perforated holes (D) and the distance between them (S) were varied to examine their effect on physical properties. The hybrid scaffolds with perforation properties of $\mathrm{D}=200, \mathrm{~S}=50 \mathrm{um}$ and $\mathrm{D}=$ $\mathrm{S}=100 \mathrm{um}$ were reported to have the most transparency and the highest tensile stress respectively. It was concluded 
that the first one had closer physical properties to the native cornea. For in vitro evaluation, human keratocytes were encapsulated in collagen gels and human corneal epithelial cells were cultured on the surface of the hybrid scaffold. The cells proliferated on the hybrid structure and protein expression of specific markers was observed with a week. However, it was reported that this time period was not sufficient to get a stratified epithelium [210].

Schubert et al. reinforced alginate hydrogels with aligned chitosan and PCL nanofibers for corneal wound healing. Transparency of the hybrid scaffold was shown to differ with the thickness of the electrospun mat., but the suturability of the hydrogel was close to the pure alginate. Further in vitro and in vivo analyses are required before considering this scaffold for reconstructing corneal wound [198]. Griffith et al. used a mixture of collagen, chitosan, and PEGDA, crosslinked with EDC/NHS for Stromal regeneration. While EDC/NHS provided short bonding between a carboxylic group of collagen to an amine group on either collagen or chitosan without interchain association, PEG-dibutyraldehyde (DBA) improved scaffold stiffness with a long-range crosslinking. High mechanical strength did not have a contradictory effect on glucose and albumin permeability. This could be related to the presence of chitosan which has been well known for its biological permeability. Developed scaffolds were transplanted into pig corneas using DLKP after removing epithelium and anterior stroma and followed up post-operatively for a year. About $60 \%$ of implanted eyes had active keratocyte cells within the scaffolds after 2 months and the mild haze was disappeared within this time period. The hybrid structure promoted epithelialization and no signs of acute inflammation were reported even after a year [202].

Short collagen-like peptides (CLPs) were combined with PEG to improve corneal regeneration. Light transmission and degradation rate of the scaffold were detected to be higher than the native cornea. ALK was used to implant the hydrogels into minipig eyes and the transplanted corneas were followed up for 12 months. Implanted corneas remained clear and both epithelium and stroma regenerated successfully [204].

For regenerating corneal endothelium, Qiao et al. crosslinked flattened and thinned dried chitosan films with poly (ethylene glycol) diglycidyl ether (PEGDGE) to get $26 \mu \mathrm{m}$ hydrogel films. The constructed scaffold was highly transparent and elastic. Although it had slightly lower ultimate stress and elastic moduli than the native tissue, its tensile strength was high. The hydrogel films had an acceptable permeability to glucose and albumin and did not show any toxic effect on sheep corneal endothelial cells [207].

\section{Conclusion and future challenges}

Ocular surface diseases are categorized into mild to very severe based on their severity. Normally, mild cases are managed by conservative measures and minor surgeries. Severe cases are managed by invasive surgeries including stem cell transplantation and corneal transplantation combined with immunosuppressive and anti-inflammatory therapies. In very severe cases artificial cornea (keratoprosthesis) may be required [211]. Although most of these approaches result in corneal regeneration, transplant rejection, incomplete epithelization, lack of the donor tissue, and invasive surgeries have highlighted the benefits of regenerative medicine for scientists $[154,212]$.

Applying regenerative medicine approaches for corneal regeneration is divided into different categories: scaffoldfree cell and growth factor delivery, non-hydrogel and hydrogel-based scaffolds. All approaches aim to heal the damaged tissue using either host healthy cells or delivered cells/growth factors. The desired scaffold for corneal regeneration should be suturable, transparent, biocompatible, biodegradable, and have a proper structure including the possibility of diffusion of nutrients into a scaffold and waste out of it, and a dome-shaped structure to make it easy to suture (Fig. 6).

Since in both growth factor and cell sheet deliveries the requirement of biomaterials is excluded, they have been applied for clinical trials. The former is derived from an autologous blood source, so it prevents the further possibility of rejection or infection [14]. Although it is clinically used for healing ocular surface diseases, it is not applicable to severe injuries [211]. Fibrin is another natural biomaterial that can be derived from an autologous blood source [67]. It is used as a substrate for various cell sources [172], the source of different growth factors [67] and glue that eliminates suturing [213].

Cell sheets are more useful for epithelial cell delivery than endothelial cell delivery because of their limited cell sources [27]. Tissue regeneration using allogenous tissue such as AM also has become clinical especially for corneal epithelium regeneration because of its promising results and it is known as traditional therapy for less severe diseases [211].

Decellularized scaffolds were provided by various sources such as cadaver or animal cornea [144, 150, 153], anterior lens capsule [8, 148], and fish scale [154]. These scaffolds have been used for treating corneal epithelial, stromal, and endothelial defects because they are suturable, biocompatible, biodegradable and permeable to biomolecules (Fig. 6). However, they get semi-transparent after decellularization and may induce inflammation and rejection. As a proper alternative, hydrogel-based scaffolds have 


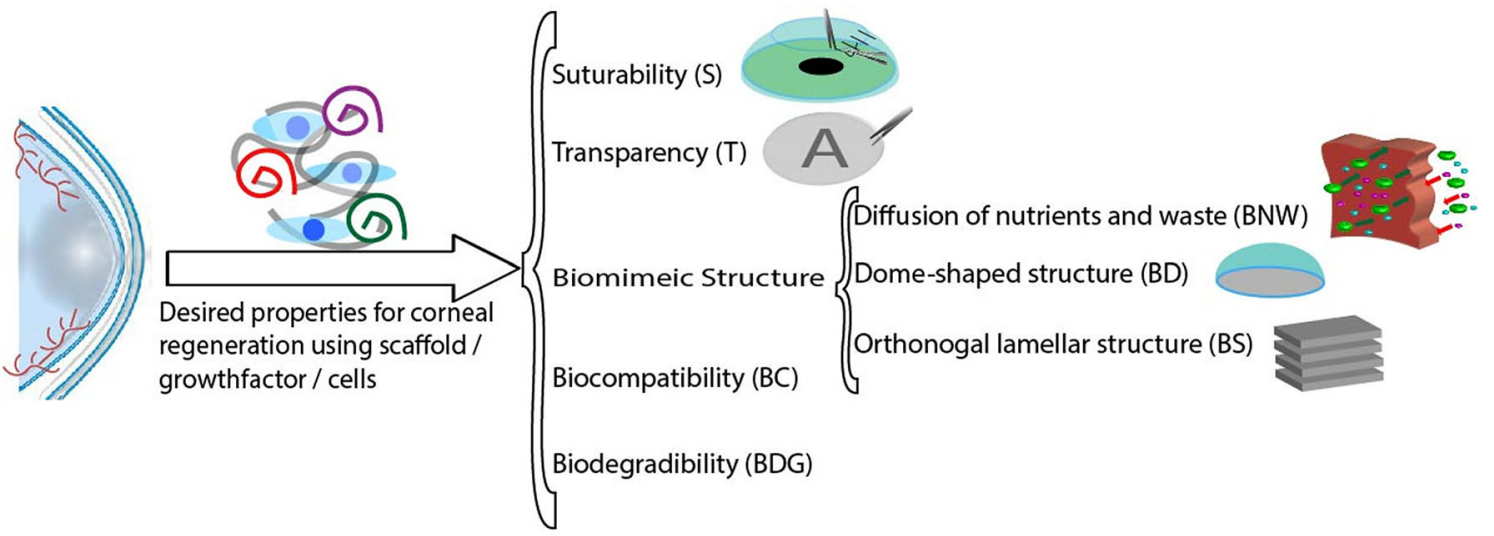

\begin{tabular}{l|c|c|c|c|c|c|c|}
\cline { 2 - 7 } \multicolumn{1}{l|}{} & S & T & BNW & BD & BS & BC & BDG \\
\hline $\begin{array}{l}\text { Hydrogel-based } \\
\text { Scaffolds }\end{array}$ & & $*$ & $*$ & $*$ & $* 1$ & $*$ & $*$ \\
\hline $\begin{array}{l}\text { Non-hydrogel-based } \\
\text { Scaffolds }\end{array}$ & $*$ & & $*$ & $*$ & $* 2$ & $*$ & $*$ \\
\hline
\end{tabular}
$\begin{aligned} & \text { 1. Using sterelithography technique } \\
& \text { 2. Using electrospinning technique }\end{aligned}$

Fig. 6 Schematic of corneal regeneration. Desired properties for scaffolds for corneal regeneration and various approaches of regenerative medicine. Acronyms of desired properties for healing injured tissue were mentioned to compare the advantages of each approach

attracted scientists' attention for healing injured corneal tissue especially damaged stroma. It is not only because of their 3D environment but also because of their high water content, acceptable nutrients penetration, transparency, biocompatibility, and biodegradability [31]. Besides the mentioned properties, surface topography has an undeniable effect on cell alignment. It was shown that the human keratocyte cell proliferation rate was higher on micropatterned scaffolds [170]. Molded RGD-functionalized silk using PDMS was reported to have satisfactory optical and mechanical properties with cultured hCSSCs on it in comparison with substrates seeded by human corneal fibroblasts (hCFs) [158]. HCFs cultured on groove-patterned silk-based scaffold expressed collagen type $\mathrm{V}$ and other corneal stromal markers [159]. It was also shown that transparency and mechanical properties of stretched compressed collagen were close to the native cornea in comparison with not stretched collagen hydrogel. Although stromal cells (keratocytes) are dendritic shaped in the native cornea, they shift into spindle-shaped fibroblasts or polygonal corneal myofibroblast in serum. Despite this fact, it is observed that they shift to keratocyte cells in collagen after a week of culture with serum [214]. Cultured keratocyte cells on groove-patterned silk film also elongated towards the grooves and resulted in orderly aligned cells in comparison with cells cultured on unpatterned films. However, the expression of keratocyte cell markers did not differ between patterned and unpatterned groups. It is reported that applying a dome-shaped strain on films improved protein expression levels. As it was expected, applying dome-shaped strain on patterned films enhanced the amount of lumican, keratocan, collagen I, and collagen $\mathrm{V}$ significantly. Therefore, both mechanical strength and surface topography affect cell behavior remarkably [215]. Soft lithography and 3D bioprinting are recent approaches in corneal regeneration and getting more popular in treating corneal diseases. In both techniques, the $3 \mathrm{D}$ computerized model is converted to the biomaterial using UV irradiation or other physical/chemical crosslinking methods $[28,158]$.

Since collagen is the main constituent of the corneal stroma, it is the most used biomaterial in stroma regeneration. Both collagen types I and III were used for healing the damaged tissue $[9,60]$. Both collagen types improved corneal stromal cell proliferation and activity so that they have been used in clinical trials [5, 100]. However, synthetic biomaterials were utilized for corneal regeneration because of their higher mechanical strength and shape ability [32]. Despite reported inflammatory immune responses for PEG in in vivo experiments, it has been attractive because of its mechanical properties and tunable features. The combination of synthetic and natural biomaterials covers the disadvantages of each and improves their advantages. For instance, collagen was added to PVA [200, 201], PEG [202], and PCL [199] to improve their biocompatibility, stromal and epithelial cell adherence, migration, and proliferation. The mixture of natural biomaterials such as collagen with chitosan [11], alginate [173], gelatin [174], and HA [11] are also used for corneal 
epithelium and stromal regeneration. The PEG-based scaffold [73] and the combination of chitosan and alginate [175] have also been applied for endothelial layer regeneration.

Besides biomaterials, cell sources are also important for tissue regeneration. Corneal autologous cell sources are favorable for unilateral ocular surface diseases which have also been applied in clinical treatment [211]. In bilateral ocular surface diseases, either other autologous cell sources such as oral mucosal epithelium [136] and nasal mucosal epithelial cell [141] or allogenous cell sources [160] are used. Mesenchymal stem cells are used both as a cell source [191, 203] and immunosuppressive for other allogenous cell sources [203, 216]. It is favorable because of their various cell sources such as dental pulp [91], bone marrow [117] and fat [216]. Corneal stromal stem cells, keratocytes, and mesenchymal stem cells have been studied for healing damaged stroma [82, 217]. An important goal of all regenerative medicine approaches is the elimination of the donor tissue. Hence, using the proper method to simulate the biomimetic structure of the native tissue, in addition to choosing the proper biomaterial and cell source, results in the desired scaffold for healing the injured cornea layer. Therefore, based on the required properties of the damaged corneal tissue (Fig. 6), it can be concluded that either the combination of non-hydrogel and hydrogel-based scaffolds such as hybrid scaffolds or 3D bioprinted scaffolds can mimic microstructure of native cornea more than other kinds of substrates. The new biomaterial technologies still need to go through a rigorous quality manufacturing and regulatory process in order to be taken into the first clinical testing. Many promising biomaterial technologies never reach that stage. So, equally important as mechanical and optical properties, are the regulatory compliance of the biomaterial, compliant manufacturing process, appropriate sterilization method, storage, shelf life and etc.

Acknowledgement This project has received funding from the Sharif University of Technology under Grant Number of G960111.

\section{Compliance with ethical standards}

Conflict of interest The authors declare no conflict of interest.

Ethical statement There are no animal or clinical experiments carried out for this paper.

\section{References}

1. Ruberti JW, Zieske JD. Prelude to corneal tissue engineering: gaining control of collagen organization. Prog Retin Eye Res. 2008;27:549-77.
2. Rafat M, Matsuura T, Li F, Griffith M. Surface modification of collagen-based artificial cornea for reduced endothelialization. J Biomed Mater Res A. 2009;88:755-68.

3. Chirila TV, Hicks CR, Dalton PD, Vljayasekaran S, Lou X, Hong Y, et al. Artificial cornea. Prog Polym Sci. 1998;23:447-73.

4. Steinhoff G. Regenerative medicine: from protocol to patient. 1st ed. London: Springer; 2011.

5. Fagerholm P, Lagali NS, Merrett K, Jackson WB, Munger R, Liu Y, et al. A biosynthetic alternative to human donor tissue for inducing corneal regeneration: 24-month follow-up of a phase 1 clinical study. Sci Transl Med. 2010;2:46ra61.

6. Ackland P, Resnikoff S, Bourne R. World blindness and visual impairment: despite many successes, the problem is growing. Community Eye Health. 2017;30:71-3.

7. Fenglan X, Yubao L, Xiaoming Y, Hongbing L, Li Z. Preparation and in vivo investigation of artificial cornea made of nano-hydroxyapatite/poly (vinyl alcohol) hydrogel composite. J Mater Sci Mater Med. 2007;18:635-40.

8. Galal A, Perez-Santonja JJ, Rodriguez-Prats JL, Abad M, Alio J. Human anterior lens capsule as a biologic substrate for the ex vivo expansion of limbal stem cells in ocular surface reconstruction. Cornea. 2007;26:473-8.

9. Xu SC, Chow J, Liu J, Li L, Maslin JS, Chadha N, et al. Risk factors for visual impairment associated with corneal diseases in southern China. Clin Ophthalmol. 2016;10:777-82.

10. Li F, Carlsson D, Lohmann C, Suuronen E, Vascotto S, Kobuch $\mathrm{K}$, et al. Cellular and nerve regeneration within a biosynthetic extracellular matrix for corneal transplantation. Proc Natl Acad Sci U S A. 2003;100:15346-51.

11. Chen J, Li Q, Xu J, Huang Y, Ding Y, Deng H, et al. Study on biocompatibility of complexes of collagen-chitosan-sodium hyaluronate and cornea. Artif Organs. 2005;29:104-13.

12. Anitua E, de la Fuente M, Muruzabal F, Riestra A, MerayoLloves J, Orive G. Plasma rich in growth factors (PRGF) eye drops stimulates scarless regeneration compared to autologous serum in the ocular surface stromal fibroblasts. Exp Eye Res. 2015;135:118-26.

13. Wester ST, Goldberg J. Stem cells in ophthalmology. In: Demirer T, editor. New advances in stem cell transplantation, London: IntechOpen; 2012. p. 405-30.

14. Acosta L, Castro M, Fernandez M, Oliveres E, Gomez-Demmel E, Tartara L. Treatment of corneal ulcers with platelet rich plasma. Arch Soc Esp Oftalmol. 2014;89:48-52.

15. Baradaran-Rafii A, Karimian F, Javadi MA, Jafarinasab M, Hosseini M, Anisian A. Corneal graft rejection; prevalence and risk factors. JOVR. 2007;2:7-14.

16. Karamichos D. Ocular tissue engineering: current and future directions. J Funct Biomater. 2015;6:77-80.

17. Chen FM, Liu X. Advancing biomaterials of human origin for tissue engineering. Prog Polym Sci. 2016;53:86-168.

18. Steinhoff G. Regenerative medicine: from protocol to patient1. Biology of tissue regeneration. 3rd ed. Cham: Springer; 2016.

19. Birk DE, Silver FH. Kinetic analysis of collagen fibrillogenesis: II. Corneal and scleral type I collagen. Coll Relat Res. 1984;4:265-77.

20. Castner DG, Favia P, Ratner BD. Surface modification of polymeric biomaterials. New York: Plenum Press; 1997.

21. Cheung RC, Ng TB, Wong JH, Chan WY. Chitosan: an update on potential biomedical and pharmaceutical applications. Mar Drugs. 2015;13:5156-86.

22. Yang J, Yamato $M$, Nishida $K$, Hayashida $Y$, Shimizu $T$, Kikuchi A, et al. Corneal epithelial stem cell delivery using cell sheet engineering: not lost in transplantation. J Drug Target. 2006;14:471-82. 
23. Ghezzi CE, Rnjak-Kovacina J, Kaplan DL. Corneal tissue engineering: recent advances and future perspectives. Tissue Eng B Rev. 2015;21:278-87.

24. Griffith M, Polisetti N, Kuffova L, Gallar J, Forrester J, Vemuganti GK, et al. Regenerative approaches as alternatives to donor allografting for restoration of corneal function. Ocul Surf. 2012;10:170-83.

25. Duval K, Grover H, Han LH, Mou Y, Pegoraro AF, Fredberg J, et al. Modeling physiological events in $2 \mathrm{D}$ vs. 3D cell culture. Physiology. 2017;32:266-77.

26. Kapałczyńska M, Kolenda T, Przybyła W, Zajączkowska M, Teresiak A, Filas V, et al. 2D and 3D cell cultures: a comparison of different types of cancer cell cultures. Arch Med Sci. 2018;14:910-9.

27. Umemoto T, Yamato M, Nishida K, Okano T. Regenerative medicine of cornea by cell sheet engineering using temperatureresponsive culture surfaces. Chin Sci Bull. 2013;58:4349-4356.

28. Bajaj P, Schweller RM, Khademhosseini A, West JL, Bashir R. 3D biofabrication strategies for tissue engineering and regenerative medicine. Annu Rev Biomed Eng. 2014;16:247-76.

29. Shaharuddin B, Meeson A. Current perspectives on tissue engineering for the management of limbal stem cell deficiency. J Stem Cells Res: Rev Rep; 2015; 2.

30. Hanjaya-Putea D, Wanjare M, Gerecht S. Biomaterials approaches in vascular engineering: a review of past and future trends. In: Burdick JA, Mauck RL, editors. Biomaterials for tissue engineering applications. Vienna: Springer; 2011. p. 457-87.

31. El-Sherbiny IM, Yacoub MH. Hydrogel scaffolds for tissue engineering: progress and challenges. Glob Cardiol Sci Pract. 2013;2013:316-42.

32. Armentano I, Dottori M, Fortunati E, Mattioli S, Kenny JM. Biodegradable polymer matrix nanocomposites for tissue engineering: a review. Polym Degrad Stab. 2010;95:2126-46.

33. Kishore V, Alapan Y, Iyer R, Mclay R, Gurkan Umut A. Application of hydrogels in ocular tissue engineering. In: Demirci U, Khademhosseini A, editors. Gels handbook: fundamentals, properties, applications. Singapore: World Scientific Publishing; 2015. p. 137-64.

34. Kumar P, Pandit A, Zeugolis DI. Progress in corneal stromal repair: from tissue grafts and biomaterials to modular supramolecular tissue-like assemblies. Adv Mater. 2016;28:5381-99.

35. Meek KM, Fullwood NJ. Corneal and scleral collagens: a microscopist's perspective. Micron. 2001;32:261-72.

36. Lai JY, Chen KH, Hsu WM, Hsiue GH, Lee YH. Bioengineered human corneal endothelium for transplantation. Arch Ophthalmol. 2006; 124:1441-8.

37. Pipparelli A, Arsenijevic Y, Thuret G, Gain P, Nicolas M, Majo F. ROCK inhibitor enhances adhesion and wound healing of human corneal endothelial cells. PLoS One. 2013;8:e62095.

38. Okumura N, Sakamoto Y, Fujii K, Kitano J, Nakano S, Tsujimoto $\mathrm{Y}$, et al. Rho kinase inhibitor enables cell-based therapy for corneal endothelial dysfunction. Sci Rep. 2016;6:26113.

39. Okumura N, Okazaki Y, Inoue R, Kakutani K, Nakano S, Kinoshita S, et al. Effect of the rho-associated kinase inhibitor eye drop (Ripasudil) on corneal endothelial wound healing. Invest Ophthalmol Vis Sci. 2016;57:1284-92.

40. Jia Y, Li W, Duan H, Li Z, Zhou Q, Shi W. Mini-sheet injection for cultured corneal endothelial transplantation. Tissue Eng Part C Methods. 2018;24:474-9.

41. Ahmed EM. Hydrogel: preparation, characterization, and applications: a review. J Adv Res. 2015;6:105-21.

42. Haraguchi Y, Shimizu T, Yamato M, Okano T. Scaffold-free tissue engineering using cell sheet technology. RSC Adv. 2012;2:2184-90.
43. Gallo JE, Gimeno FL, Gatto SC, Croxatto JO, Ferro JI. In vivo lamellar keratoplasty using platelet-rich plasma as a bioadhesive. Eye. 2010;24:368-75.

44. Noverina R, Widowati W, Ayuningtyas W, Kurniawan D, Afifah E, Laksmitawati DR, et al. Growth factors profile in conditioned medium human adipose tissue-derived mesenchymal stem cells (CM-hATMSCs). Clin Nutr Exp. 2019;24:34-44.

45. Nakahara M, Okumura N, Kay EP, Hagiya M, Imagawa K, Hosoda Y, et al. Corneal endothelial expansion promoted by human bone marrow mesenchymal stem cell-derived conditioned medium. PLoS One. 2013;8:e69009.

46. Sugiyama H, Yamato M, Nishida K, Okano T. Evidence of the survival of ectopically transplanted oral mucosal epithelial stem cells after repeated wounding of cornea. Mol Ther. 2014;22:1544-55.

47. Ide T, Nishida K, Yamato M, Sumide T, Utsumi M, Nozaki T, et al. Structural characterization of bioengineered human corneal endothelial cell sheets fabricated on temperature-responsive culture dishes. Biomaterials. 2006;27:607-14.

48. Lai J-Y, Chen K-H, Hsiue G-H. Tissue-engineered human corneal endothelial cell sheet transplantation in a rabbit model using functional biomaterials. Transplantation. 2007;84:1222-32.

49. Hsiue GH, Lai JY, Chen KH, Hsu WM. A novel strategy for corneal endothelial reconstruction with a bioengineered cell sheet. Transplantation. 2006;81:473-6.

50. Syed-Picard FN, Du Y, Hertsenberg AJ, Palchesko R, Funderburgh ML, Feinberg AW, et al. Scaffold-free tissue engineering of lamellar corneal stromal tissue. J Tissue Eng Regen Med. 2018;12:59-69.

51. Sharma N, Singh D, Maharana PK, Kriplani A, Velpandian T, Pandey RM, et al. Comparison of amniotic membrane transplantation and umbilical cord serum in acute ocular chemical burns: a randomized controlled trial. Am J Ophthalmol. 2016;168:157-163.

52. Avila MY, Igua AM, Mora AM. Randomised, prospective clinical trial of platelet-rich plasma injection in the management of severe dry eye. Br J Ophthalmol. 2019;103:648-53.

53. Kinoshita S, Koizumi N, Ueno M, Okumura N, Imai K, Tanaka $\mathrm{H}$, et al. Injection of cultured cells with a ROCK inhibitor for bullous keratopathy. N Engl J Med. 2018;378:995-1003.

54. Sendon-Lago J, Seoane S, Martinez-Ordoñez A, Eiro N, Saa J, Vizoso FJ, et al. Corneal regeneration by conditioned medium of human uterine cervical stem cells is mediated by TIMP-1 and TIMP-2. Exp Eye Res. 2019;180:110-21.

55. Bermudez MA, Sendon-Lago J, Eiro N, Treviño M, Gonzalez F, Yebra-Pimentel E, et al. Corneal epithelial wound healing and bactericidal effect of conditioned medium from human uterine cervical stem cells. Invest Ophthalmol Vis Sci. 2015;56:983-92.

56. Liu Q, Guo Y, Liu S, Wang P, Xue Y, Cui Z, et al. Characterization of the IPSC-derived conditioned medium that promotes the growth of bovine corneal endothelial cells. Peer J. 2019;7:1-21.

57. Hoshiba T, Lu H, Kawazoe N, Chen G. Decellularized matrices for tissue engineering. Expert Opin Biol Ther. 2010;10:1717-28.

58. Nair LR, Kumary T. Cell sheet technology using human umbilical cord mesenchymal stem cells for myocardial tissue engineering. J Tissue Sci Eng. 2016;7:1-5.

59. Shimizu T. Cell sheet-based tissue engineering for fabricating 3-dimensional heart tissues. Circ J. 2014;78:2594-603.

60. Yamato M, Okano T. Cell sheet engineering. Mater Today. 2004;7:42-7.

61. Patil A, Gohil K. Biomaterials for corneal repair and regeneration. Bombay Technol. 2015; 65:1-11. 
62. Chakrabarty K, Shetty R, Ghosh A. Corneal cell therapy: with iPSCs, it is no more a far-sight. Stem Cell Res Ther. 2018;9:1-15.

63. Chen G, Qi Y, Niu L, Di T, Zhong J, Fang T, et al. Application of the cell sheet technique in tissue engineering. Biomed Rep. 2015;3:749-57.

64. Whitaker MJ, Quirk RA, Howdle SM, Shakesheff KM. Growth factor release from tissue engineering scaffolds. J Pharm Pharmacol. 2001;53:1427-37.

65. Lee K, Silva EA, Mooney DJ. Growth factor delivery-based tissue engineering: general approaches and a review of recent developments. J R Soc Interface. 2011;8:153-70.

66. Alio JL, Rodriguez AE, Wróbel Dudzińska D. Eye platelet-rich plasma in the treatment of ocular surface disorders. Curr Opin Ophthalmol. 2015;26:325-32.

67. Alio JL, Rodriguez AE, Martinez LM, Rio AL. Autologous fibrin membrane combined with solid platelet-rich plasma in the management of perforated corneal ulcers. JAMA Ophthalmol. 2013;131:745-51.

68. Chen B, Jones RR, Mi SL, Foster J, Alcock SG, Hamley IW, et al. The mechanical properties of amniotic membrane influence its effect as a biomaterial for ocular surface repair. Soft Matter. 2012;8:8379-87.

69. Hoppenreijs V, Pels E, Vrensen G, Treffers W. Corneal endothelium and growth factors. Surv Ophthalmol. 1996;41:155-64.

70. Elisseeff J, Madrid MG, Lu Q, Chae JJ, Guo Q. Future perspectives for regenerative medicine in ophthalmology. Middle East Afr J Ophthalmol. 2013;20:38-45.

71. O'Brien FJ. Biomaterials and scaffolds for tissue engineering. Mater Today. 2011;14:88-95.

72. Abbott R, Kaplan D. Engineering biomaterials for enhanced tissue regeneration. Curr Stem Cell Rep. 2016;2:140-6.

73. Ozcelik B, Brown KD, Blencowe A, Ladewig K, Stevens GW, Scheerlinck JPY, et al. Biodegradable and biocompatible poly(ethylene glycol)-based hydrogel films for the regeneration of corneal endothelium. Adv Healthc Mater. 2014;3:1496-507.

74. Ortega Í, Deshpande P, Gill AA, Macneil S, Claeyssens F. Development of a microfabricated artificial limbus with micropockets for cell delivery to the cornea. Biofabrication. 2013;5:1-11.

75. Luo Zheng L, Vanchinathan V, Dalal R, Noolandi J, Waters DJ, Hartmann L, et al. Biocompatibility of poly(ethylene glycol) and poly(acrylic acid) interpenetrating network hydrogel by intrastromal implantation in rabbit cornea. J Biomed Mater Res A. $2015 ; 103: 3157-65$.

76. Sharma S, Mohanty S, Gupta D, Jassal M, Agrawal AK, Tandon R. Cellular response of limbal epithelial cells on electrospun poly- $\varepsilon$-caprolactone nanofibrous scaffolds for ocular surface bioengineering: a preliminary in vitro study. Mol Vis. 2011;17:2898-910.

77. Baradaran-Rafii A, Biazar E, Heidari-Keshel S. Cellular response of limbal stem cells on polycaprolactone nanofibrous scaffolds for ocular epithelial regeneration. Curr Eye Res. 2016;41:326-33.

78. Kruse M, Walter P, Bauer B, Rütten S, Schaefer K, Plange N, et al. Electrospun membranes as scaffolds for human corneal endothelial cells. Curr Eye Res. 2018;43:1-11.

79. Salehi S, Fathi M, Javanmard SH, Bahners T, Gutmann JS, Ergün S, et al. Generation of PGS/PCL blend nanofibrous scaffolds mimicking corneal stroma structure. Macromol Mater Eng. 2014;299:455-69.

80. Wang J, Gao C, Zhang Y, Wan Y. Preparation and in vitro characterization of BC/PVA hydrogel composite for its potential use as artificial cornea biomaterial. Mater Sci Eng C Mater Biol Appl. 2010;30:214-8.
81. Wu J, Du Y, Watkins SC, Funderburgh JL, Wagner WR. The engineering of organized human corneal tissue through the spatial guidance of corneal stromal stem cells. Biomaterials. 2012;33:1343-52.

82. Wu J, Du Y, Mann MM, Yang E, Funderburgh JL, Wagner WR. Bioengineering organized, multilamellar human corneal stromal tissue by growth factor supplementation on highly aligned synthetic substrates. Tissue Eng Part A. 2013;19:2063-75.

83. Ortega Í, Ryan AJ, Deshpande P, MacNeil S, Claeyssens F. Combined microfabrication and electrospinning to produce 3-D architectures for corneal repair. Acta Biomater. 2013;9:5511-20.

84. Ortega I, Sefat F, Deshpande P, Paterson T, Ramachandran C, Ryan A, Macneil S, et al. Combination of microstereolithography and electrospinning to produce membranes equipped with niches for corneal regeneration. J Vis Exp. 2014;91:e51826.

85. Deshpande P, McKean R, Blackwood KA, Senior RA, Ogunbanjo A, Ryan AJ, et al. Using poly(lactide-co-glycolide) electrospun scaffolds to deliver cultured epithelial cells to the cornea. Regen Med. 2010;5:395-401.

86. Baradaran-Rafii A, Biazar E, Heidari-Keshel S. Cellular response of stem cells on nanofibrous scaffold for ocular surface bioengineering. ASAIO J. 2015;61:605-12.

87. Aslan B, Guler S, Tevlek A, Aydin HM. Evaluation of collagen foam, poly(l-lactic acid) nanofiber mesh, and decellularized matrices for corneal regeneration. J Biomed Mater Res B Appl Biomater. 2018;106:2157-68.

88. Sipehia R, Garfinkle A, Jackson WB, Chang TM. Towards an artificial cornea: surface modifications of optically clear, oxygen permeable soft contact lens materials by ammonia plasma modification technique for the enhanced attachment and growth of corneal epithelial cells. Biomater Artif Cells Artif Organs. 1990;18:643-55.

89. Pellegrini G, Traverso CE, Franzi AT, Zingirian M, Cancedda $\mathrm{R}$, De Luca M. Long-term restoration of damaged corneal surfaces with autologous cultivated corneal epithelium. Lancet. 1997;349:990-3.

90. Di Girolamo N, Bosch M, Zamora K, Coroneo MT, Wakefield D, Watson SL. A contact lens-based technique for expansion and transplantation of autologous epithelial progenitors for ocular surface reconstruction. Transplantation. 2009;87:1571-8.

91. Kushnerev E, Shawcross SG, Sothirachagan S, Carley F, Brahma A, Yates JM, et al. Regeneration of corneal epithelium with dental pulp stem cells using a contact lens delivery system. Invest Ophthalmol Vis Sci. 2016;57:5192-9.

92. Choi JA, Chung SH. Combined application of autologous serum eye drops and silicone hydrogel lenses for the treatment of persistent epithelial defects. Eye Contact Lens. 2011;37:370-3.

93. Di Girolamo N, Chui J, Wakefield D, Coroneo MT. Cultured human ocular surface epithelium on therapeutic contact lenses. Br J Ophthalmol. 2007;91:459-64.

94. Ashammakhi N, Ndreu A, Nikkola L, Wimpenny I, Yang Y. Advancing tissue engineering by using electrospun nanofibers. Regen Med. 2008;3:547-74.

95. Blakeney B, Tambralli A, Anderson J, Andukuri A, Lim D, Dean D, et al. Cell infiltration and growth in a low density, uncompressed three-dimensional electrospun nanofibrous scaffold. Biomaterials. 2011;32:1583-90.

96. Gupta H, Aqil M. Contact lenses in ocular therapeutics. Drug Discov Today. 2012;17:522-7.

97. Bobba S, Di Girolamo N. Contact lenses: a delivery device for stem cells to treat corneal blindness. Optom Vis Sci. 2016;93:412-8.

98. Blackmore SJ. The use of contact lenses in the treatment of persistent epithelial defects. Contact Lens Anterior Eye. 2010;33:239-44. 
99. Deshpande P, Notara M, Bullett N, Daniels JT, Haddow DB, MacNeil S. Development of a surface-modified contact lens for the transfer of cultured limbal epithelial cells to the cornea for ocular surface diseases. Tissue Eng Part A. 2009;15:2889-902.

100. Tummala GK, Joffre T, Lopes VR, Liszka A, Buznyk O, Ferraz $\mathrm{N}$, et al. Hyperelastic nanocellulose-reinforced hydrogel of high water content for ophthalmic applications. ACS Biomater Sci Eng. 2016;2:2072-9.

101. de Jong B, van der Meulen IJE, van Vliet JMJ, Lapid-Gortzak R, Nieuwendaal CP, van den Berg TJTP. Effects of corneal scars and their treatment with rigid contact lenses on quality of vision. Eye Contact Lens. 2018;44:216-220.

102. Conway ST, Wagdi SF. Corneal scarring associated with daily soft contact lens wear. Ann Ophthalmol. 1983;15:868-71.

103. Wen Q, Dong Y. Fundumentals of hydrogels. In: Demirci U, Khademhosseini A, editors. Gels handbook: fundamentals, properties, applications. Singapore: World Scientific Publishing; 2016.

104. Myung D, Farooqui N, Zheng LL, Koh W, Noolandi J, Cochran $\mathrm{JR}$, et al. Bioactive interpenetrating polymer network hydrogels that support corneal epithelial wound healing. J Biomed Mater Res A. 2009;90:70-81.

105. Ishino Y, Sano Y, Nakamura T, Connon CJ, Rigby H, Fullwood $\mathrm{NJ}$, et al. Amniotic membrane as a carrier for cultivated human corneal endothelial cell transplantation. Invest Ophthalmol Vis Sci. 2004;45:800-6.

106. Shao Y, Yu Y, Pei C-G, Zhou Q, Liu Q-P, Tan G, et al. Evaluation of novel decellularizing corneal stroma for cornea tissue engineering applications. Int J Ophthalmol. 2012;5:415-8.

107. Liu Y, Gan L, Carlsson DJ, Fagerholm P, Lagali N, Watsky MA, et al. A simple, cross-linked collagen tissue substitute for corneal implantation. Invest Ophthalmol Vis Sci. 2006;47:1869-75.

108. Merrett K, Fagerholm P, McLaughlin CR, Dravida S, Lagali N, Shinozaki N, et al. Tissue-engineered recombinant human collagen-based corneal substitutes for implantation: performance of type I versus type III collagen. Invest Ophthalmol Vis Sci. 2008;49:3887-94.

109. Ahn JL, Kuffova L, Merrett K, Mitra D, Forrester JV, Li F, et al. Crosslinked collagen HYDROGELS as corneal implants: effects of sterically bulky vs. non-bulky carbodiimides as crosslinkers. Acta Biomater. 2013;9:7796-805.

110. Fagerholm P, Lagali N, Carlsson D, Merrett K, Griffith M. Corneal regeneration following implantation of a biomimetic tissue-engineered substitute. Clin Transl Sci. 2009;2:162-4.

111. Liu W, Merrett K, Griffith M, Fagerholm P, Dravida S, Heyne $\mathrm{B}$, et al. Recombinant human collagen for tissue engineered corneal substitutes. Biomaterials. 2008;29:1147-58.

112. Liu Y, Griffith M, Watsky MA, Forrester JV, Kuffová L, Grant $\mathrm{D}$, et al. Properties of porcine and recombinant human collagen matrices for optically clear tissue engineering applications. Biomacromol. 2006;7:1819-28.

113. Long Y, Zhao X, Liu S, Chen M, Liu B, Ge J, et al. Collagenhydroxypropyl methylcellulose membranes for corneal regeneration. ACS Omega. 2018;3:1269-75.

114. Duan X, Sheardown H. Dendrimer crosslinked collagen as a corneal tissue engineering scaffold: mechanical properties and corneal epithelial cell interactions. Biomaterials. 2006;27:4608-17.

115. Zhang J, Sisley A, Anderson A, Taberner A, McGhee C, Patel D. Characterisation of a novel collagen scaffold for corneal tissue engineering. Tissue Eng Part C Methods. 2016;22:165-72.

116. Cherfan D, Verter EE, Melki S, Gisel TE, Doyle FJ, Scarcelli G, et al. Collagen cross-linking using rose bengal and green light to increase corneal stiffness. Invest Ophthalmol Vis Sci. 2013;54:3426-33.
117. Koulikovska M, Rafat M, Petrovski G, Veréb Z, Akhtar S, Fagerholm $P$, et al. Enhanced regeneration of corneal tissue via a bioengineered collagen construct implanted by a nondisruptive surgical technique. Tissue Eng Part A. 2015;21:1116-30.

118. Pasyechnikova N, Vit V, Leus M, Iakymenko S, Buznyk O, Kolomiichuk S, et al. Collagen-based bioengineered substitutes of donor corneal allograft implantation: assessment and hypotheses. Med Hypothesis Discov Innov Ophthalmol J. 2012;1:10-3.

119. Vrana NE, Builles N., Kocak H, Gulay P, Damour O, Malbouyres $\mathrm{M}$. et al. EDC/NHS crosslinked collagen foams as scaffolds for artificial corneal stroma. J Biomater Sci. 2007;18:1527-1545.

120. Lagali N, Griffith M, Fagerholm P, Merrett K, Huynh M, Munger R. Innervation of tissue-engineered recombinant human collagen-based corneal substitutes: a comparative in vivo confocal microscopy study. Invest Ophthalmol Vis Sci. 2008;49:3895-901.

121. Mi S, Khutoryanskiy VV, Jones RR, Zhu X, Hamley IW, Connon CJ. Photochemical cross-linking of plastically compressed collagen gel produces an optimal scaffold for corneal tissue engineering. J Biomed Mater Res A. 2011;99:1-8.

122. Mimura T, Yamagami S, Yokoo S, Usui T, Tanaka K, Hattori S, et al. Cultured human corneal endothelial cell transplantation with a collagen sheet in a rabbit model. Invest Ophthalmol Vis Sci. 2004;45:2992-7.

123. Spinozzi D, Miron A, Bruinsma M, Dapena I, Lavy I, Binder PS, et al. Evaluation of the suitability of biocompatible carriers as artificial transplants using cultured porcine corneal endothelial cells. Curr Eye Res. 2019;44:243-9.

124. Lee HJ, Fernandes-Cunha GM, Na KS, Hull SM, Myung D. Bioorthogonally crosslinked, in situ-forming corneal stromal tissue substitute. Adv Heal Mater. 2018;7:139-48.

125. Liu W, Deng C, McLaughlin CR, Fagerholm P, Lagali NS, Heyne B, et al. Collagen-phosphorylcholine interpenetrating network hydrogels as corneal substitutes. Biomaterials. 2009;30:1551-9.

126. Islam MM, Cepla V, He C, Edin J, Rakickas T, Kobuch K, et al. Functional fabrication of recombinant human collagen-phosphorylcholine hydrogels for regenerative medicine applications. Acta Biomater. 2015;12:70-80.

127. Islam MM, Buznyk O, Reddy JC, Pasyechnikova N, Alarcon EI, Hayes S, Lewis P, Fagerholm P, et al. Biomaterials-enabled cornea regeneration in patients at high risk for rejection of donor tissue transplantation. NPJ Regen Med. 2018;3:2.

128. Fagerholm P, Lagali NS, Ong JA, Merrett K, Jackson WB, Polarek JW, Suuronen EJ, et al. Stable corneal regeneration four years after implantation of a cell-free recombinant human collagen scaffold. Biomaterials. 2014;35:2420-7.

129. McLaughlin CR, Acosta MC, Luna C, Liu W, Belmonte C, Griffith M, et al. Regeneration of functional nerves within full thickness collagen-phosphorylcholine corneal substitute implants in guinea pigs. Biomaterials. 2010;31:2770-8.

130. Yoshida J, Oshikata-Miyazaki A, Yokoo S, Yamagami S, Takezawa T, Amano S. Development and evaluation of porcine atelocollagen vitrigel membrane with a spherical curve and transplantable artificial corneal endothelial grafts. Invest Ophthalmol Vis Sci. 2014;55:4975-81.

131. Insler MS, Lopez JG. Microcarrier cell culture of neonatal human corneal endothelium. Curr Eye Res. 1990;9:23-30.

132. Levis HJ, Peh GS, Toh KP, Poh R, Shortt AJ, Drake RAL, et al. Plastic compressed collagen as a novel carrier for expanded human corneal endothelial cells for transplantation. PLoS One. 2012;7:e50993.

133. Shojaati G, Khandaker I, Sylakowski K, Funderburgh ML, Du Y, Funderburgh JL. Compressed collagen enhances stem cell 
therapy for corneal scarring. Stem Cells Transl Med. 2018;7:487-94.

134. Koivusalo L, Karvinen J, Sorsa E, Jönkkäri I, Väliaho J, Kallio $\mathrm{P}$, et al. Hydrazone crosslinked hyaluronan-based hydrogels for therapeutic delivery of adipose stem cells to treat corneal defects. Mater Sci Eng C Mater Biol Appl. 2018;85:68-78.

135. Duarte Campos DF, Rohde M, Ross M, Anvari P, Blaeser A, Vogt $\mathrm{M}$, et al. Corneal bioprinting utilizing collagen-based bioinks and primary human keratocytes. J Biomed Mater Res A. 2019;107:1945-53.

136. Inatomi T, Nakamura T, Koizumi N, Sotozono C, Kinoshita S. Current concepts and challenges in ocular surface reconstruction using cultivated mucosal epithelial transplantation. Cornea. 2005;24:32-8.

137. Man RC, Yong TK, Hwei NM, Halim WH, Zahidin AZ, Ramli $\mathrm{R}$, Saim $\mathrm{AB}$, Idrus $\mathrm{RB}$, et al. Corneal regeneration by induced human buccal mucosa cultivated on an amniotic membrane following alkaline injury. Mol Vis. 2017;23:810-22.

138. de Farias CC, Allemann N, Gomes JAP. Randomized trial comparing amniotic membrane transplantation with lamellar corneal graft for the treatment of corneal thinning. Cornea. 2016;35:438-44.

139. Connon CJ, Doutch J, Chen B, Hopkinson A, Mehta JS, Nakamura T, et al. The variation in transparency of amniotic membrane used in ocular surface regeneration. Br J Ophthalmol. 2010;94:1057-61.

140. Lai JY, Ma DH. Glutaraldehyde cross-linking of amniotic membranes affects their nanofibrous structures and limbal epithelial cell culture characteristics. Int $J$ Nanomedicine. 2013;8:4157-68.

141. Kobayashi M, Nakamura T, Yasuda M, Hata Y, Okura S, Iwamoto $\mathrm{M}$, et al. Ocular surface reconstruction with a tissueengineered nasal mucosal epithelial cell sheet for the treatment of severe ocular surface diseases. Stem Cells Transl Med. 2015;4:99-109.

142. Schwab IR, Reyes M, Isseroff RR. Successful transplantation of bioengineered tissue replacements in patients with ocular surface disease. Cornea. 2000;19:421-6.

143. Asl NS, Nejat F, Mohammadi P, Nekoukar A, Hesam S, Ebrahimi M, et al. Amniotic membrane extract eye drop promotes limbal stem cell proliferation and corneal epithelium healing. Cell J. 2019;20:459-68.

144. Ponce Márquez S, Martínez V, McIntosh Ambrose W, Wang J, Gantxegui N, Schein O, et al. Decellularization of bovine corneas for tissue engineering applications. Acta Biomater. 2009;5:1839-47.

145. Hatami-Marbini H, Rahimi A. Interrelation of hydration, collagen cross-linking treatment, and biomechanical properties of the cornea. Curr Eye Res. 2016;41:616-22.

146. Choi JS, Williams JK, Greven M, Walter KA, Laber PW, Khang $\mathrm{G}$, et al. Bioengineering endothelialized neo-corneas using donor-derived corneal endothelial cells and decellularized corneal stroma. Biomaterials. 2010;31:6738-45.

147. Ma XY, Zhang Y, Zhu D, Lu Y, Zhou G, Liu W, et al. Corneal stroma regeneration with acellular corneal stroma sheets and keratocytes in a rabbit model. PLoS One. 2015;10:e0132705.

148. Yoeruek E, Saygili O, Spitzer M, Tatar O, Bartz-Schmidt K, Szurman P. Human anterior lens capsule as carrier matrix for cultivated human corneal endothelial cells. Cornea. 2009;28:416-20.

149. Kopsachilis N, Tsinopoulos I, Tourtas T, Kruse F, Luessen U. Descemet's membrane substrate from human donor lens anterior capsule. Clin Exp Ophthalmol. 2012;40:187-94.

150. Bayyoud T, Thaler S, Hofmann J, Maurus C, Spitzer MS, BartzSchmidt $\mathrm{KU}$, et al. Decellularized bovine corneal posterior lamellae as carrier matrix for cultivated human corneal endothelial cells. Curr Eye Res. 2012;37:179-86.

151. Alió del Barrio JL, El Zarif M, Azaar A, Makdissy N, Khalil C, Harb W, et al. Corneal stroma enhancement with decellularized stromal laminas with or without stem cell recellularization for advanced keratoconus. Am J Ophthalmol. 2018;186:47-58.

152. Yin H, Qiu P, Wu F, Zhang W, Teng W, Qin Z, et al. Construction of a corneal stromal equivalent with SMILE-derived lenticules and fibrin glue. Sci Rep. 2016;6:33848.

153. Yoeruek E, Bayyoud T, Maurus C, Hofmann J, Spitzer MS, Bartz-Schmidt KU, et al. Decellularization of porcine corneas and repopulation with human corneal cells for tissue-engineered xenografts. Acta Ophthalmol. 2012;90:125-31.

154. Huibertus van Essen T, Lin CC, Hussain AK, Maas S, Lai HJ, Linnartz $\mathrm{H}$, et al. A fish scale-derived collagen matrix as artificial cornea in rats: properties and potential. Invest Ophthalmol Vis Sci. 2013;54:3224-33.

155. Reichl S, Borrelli M, Geerling G. Keratin films for ocular surface reconstruction. Biomaterials. 2011;32:3375-86.

156. Wang W, Despanie J, Shi P, Edman-Woolcott MC, Lin YA, Cui $\mathrm{H}$, et al. Lacritin-mediated regeneration of the corneal epithelia by protein polymer nanoparticles. $\mathrm{J}$ Mater Chem $\mathrm{B}$. 2014;2:8131-41.

157. Lu PL, Lai JY, Ma DH, Hsiue GH. Carbodiimide cross-linked hyaluronic acid hydrogels as cell sheet delivery vehicles: characterization and interaction with corneal endothelial cells. J Biomater Sci Polym Ed. 2008;19:1-18.

158. Ghezzi CE, Marelli B, Omenetto FG, Funderburgh JL, Kaplan DL. 3D functional corneal stromal tissue equivalent based on corneal stromal stem cells and multi-layered silk film architecture. PLoS One. 2017;12:e169504.

159. Gil ES, Park SH, Marchant J, Omenetto F, Kaplan DL. Response of human corneal fibroblasts on silk film surface patterns. Macromol Biosci. 2010;10:664-73.

160. Liu J, Lawrence BD, Liu A, Schwab IR, Oliveira LA, Rosenblatt MI. Silk fibroin as a biomaterial substrate for corneal epithelial cell sheet generation. Invest Ophthalmol Vis Sci. 2010;53:4130-8.

161. Choi JH, Jeon H, Song JE, Oliveira JM, Reis RL, Khang G. Biofunctionalized lysophosphatidic acid/silk fibroin film for cornea endothelial cell regeneration. Nanomaterials (Basel). 2018;8:290.

162. Hazra S, Nandi S, Naskar D, Guha R, Chowdhury S, Pradhan N. Non-mulberry silk fibroin biomaterial for corneal regeneration. Sci Rep. 2016;6:21840.

163. Lai JY, Li YT, Cho CH, Yu TC. Nanoscale modification of porous gelatin scaffolds with chondroitin sulfate for corneal stromal tissue engineering. Int $\mathrm{J}$ Nanomedicine. 2012;7:1101-14.

164. Niu G, Choi JS, Wang Z, Skardal A, Giegengack M, Soker S. Heparin-modified gelatin scaffolds for human corneal endothelial cell transplantation. Biomaterials. 2014;35:4005-14.

165. Watanabe R, Hayashi R, Kimura Y, Tanaka Y, Kageyama T, Hara S, et al. A novel gelatin hydrogel carrier sheet for corneal endothelial transplantation. Tissue Eng Part A. 2011;17:2213-9.

166. Momenzadeh D, Baradaran-Rafii A, Keshel SH, Ebrahimi M, Biazar E. Electrospun mat with eyelid fat-derived stem cells as a scaffold for ocular epithelial regeneration. Artif Cells Nanomed Biotechnol. 2017;45:120-7.

167. Li L, Lu C, Wang L, Chen M, White J, Hao X, et al. Gelatinbased photocurable hydrogels for corneal wound repair. ACS Appl Mater Interfaces. 2018;10:13283-92.

168. Lai JY, Luo LJ, Ma DH. Effect of cross-linking density on the structures and properties of carbodiimide-treated gelatin matrices as limbal stem cell niches. Int J Mol Sci. 2018;19:3294. 
169. Rizwan M, Peh GSL, Ang HP, Lwin NC, Adnan K, Mehta JS, et al. Sequentially-crosslinked bioactive hydrogels as nano-patterned substrates with customizable stiffness and degradation for corneal tissue engineering applications. Biomaterials. 2017;120:139-54.

170. Koo S, Ahn SJ, Zhang H, Wang JC, Yim EKF. Human corneal keratocyte response to micro-and nano-gratings on chitosan and PDMS. Cell Mol Bioeng. 2011;4:399-410.

171. Shojaati G, Khandaker I, Funderburgh ML, Mann MM, Basu R, Stolz DB, et al. Mesenchymal stem cells reduce corneal fibrosis and inflammation via extracellular vesicle-mediated delivery. Stem Cells Transl Med. 2019;8:1192-201.

172. Alaminos M, Sánchez-Quevedo MDC, Muñoz-Ávila JI, Serrano D, Medialdea S, Carreras I, et al. Construction of a complete rabbit cornea substitute using a fibrin-agarose scaffold. Invest Ophthalmol Vis Sci. 2006;47:3311-7.

173. Wu Z, Su X, Xu Y, Kong B, Sun W, Mi S. Bioprinting threedimensional cell-laden tissue constructs with controllable degradation. Sci Rep. 2016;6:24474.

174. Liu Y, Ren L, Wang Y. Crosslinked collagen-gelatin-hyaluronic acid biomimetic film for cornea tissue engineering applications. Mater Sci Eng C Mater Biol Appl. 2013;33:196-201.

175. Liang Y, Liu W, Han B, Yang C, Ma Q, Song F, et al. An in situ formed biodegradable hydrogel for reconstruction of the corneal endothelium. Colloids Surfaces B Biointerfaces. 2011;82:1-7.

176. Tonsomboon K, Oyen ML. Composite electrospun gelatin fiberalginate gel scaffolds for mechanically robust tissue engineered cornea. J Mech Behav Biomed Mater. 2013;21:185-94.

177. Heidari Keshel S, Rostampour M, Khosropour G, Bandbon BA, Baradaran-Rafii A, Biazar E. Derivation of epithelial-like cells from eyelid fat-derived stem cells in thermosensitive hydrogel. J Biomater Sci Polym Ed. 2016;27:339-50.

178. Wright B, Mi S, Connon CJ. Towards the use of hydrogels in the treatment of limbal stem cell deficiency. Drug Discov Today. 2013;18:79-86.

179. Ramos T, Scott D, Ahmad S. An update on ocular surface epithelial stem cells: cornea and conjunctiva. Stem Cells Int. 2015;2015:601731.

180. Ahmad S. Concise review: limbal stem cell deficiency, dysfunction, and distress. Stem Cells Transl Med. 2012;1:110-5.

181. Tsai RJ, Li LM, Chen JK. Reconstruction of damaged corneas by transplantaion of autologous limbal epithelial cells. N Engl J Med. 2000;343:86-93.

182. Kobayashi H, Hattori S, Honda T, Kameda T, Tamada, Y. Long term implantation of silk fibroin nanofiber in rabbit cornea as a scaffold for corneal stromal regeneration. Front Bioeng Biotechnol. 2016. https://www.frontiersin.org/10.3389/conf. FBIOE.2016.01.01881/event_abstract.

183. Borrelli M, Joepen N, Reichl S, Finis D, Schoppe M, Geerling $\mathrm{G}$, et al. Keratin films for ocular surface reconstruction: evaluation of biocompatibility in an in vivo model. Biomaterials. 2015;42:112-20.

184. Navaratnam J, Utheim TP, Rajasekhar VK, Shahdadfar A. Substrates for expansion of corneal endothelial cells towards bioengineering of human corneal endothelium. J Funct Biomater. 2015;6:917-45.

185. Chircov C, Grumezescu AM, Bejenaru LE. Hyaluronic acidbased scaffolds for tissue engineering. Rom J Morphol Embryol. 2018;59:71-6.

186. Lai JY. Influence of pre-freezing temperature on the corneal endothelial cytocompatibility and cell delivery performance of porous hyaluronic acid hydrogel carriers. Int $\mathrm{J}$ Mol Sci. 2015;16:18796-811.

187. Gomes JAP, Amankwah R, Powell-Richards A, Dua HS. Sodium hyaluronate (hyaluronic acid) promotes migration of human corneal epithelial cells in vitro. $\mathrm{Br} \mathrm{J}$ Ophthalmol. 2004;88:821-5.

188. Choi B, Loh XJ, Tan A, Loh CK, Ye E, Joo MK, et al. Introduction to in situ forming hydrogels for biomedical applications. In: Loh X, editor. In-situ gelling polymers. Series in bioengineering. Singapore: Springer; 2015. p. 5-35.

189. Jin R. In-situ forming biomimetic hydrogels for tissue regeneration. In: Lin C, editor. Biomedicine. London: IntechOpen; 2012.

190. Irimia T, Dinu-Pîrvu CE, Ghica MV, Lupuleasa D, Muntean DL, Udeanu DI, et al. Chitosan-based in situ gels for ocular delivery of therapeutics: a state-of-the-art review. Mar Drugs. 2018; 16:373.

191. Zhao X, Song W, Liu S, Ren L. Corneal regeneration by utilizing collagen based materials. Sci China Chem. 2016;59:1548-53.

192. McLaughlin C, Fagerholm P, Muzakare L, Lagali N, Forrester J, Kuffová L, et al. Regeneration of corneal cells and nerves in an implanted collagen corneal substitute. Cornea. 2008;27:580-9.

193. Ludwig PE, Huff TJ, Zuniga JM. The potential role of bioengineering and three-dimensional printing in curing global corneal blindness. J Tissue Eng. 2018;9:2041731418769863.

194. Isaacson A, Swioklo S, Connon CJ. 3D bioprinting of a corneal stroma equivalent. Exp Eye Res. 2018;173:188-93.

195. Lai JY, Ma DH, Cheng HY, Sun CC, Huang SJ, Li YT, et al. Ocular biocompatibility of carbodiimide cross-linked hyaluronic acid hydrogels for cell sheet delivery carriers. J Biomater Sci Polym Ed. 2010;21:359-76.

196. Wang Y, Zhang W, Yuan J, Shen J. Differences in cytocompatibility between collagen, gelatin and keratin. Mater Sci Eng C. Mater Biol Appl. 2016;59:30-4.

197. Rose JB, Pacelli S, El Haj AJ, Dua HS, Hopkinson A, White LJ, et al. Gelatin-based materials in ocular tissue engineering. Materials (Basel). 2014;7:3106-35.

198. Stafiej P, Küng F, Kruse FE, Schubert DW, Fuchsluger TA. Mechanical and optical properties of PCL nanofiber reinforced alginate hydrogels for application in corneal wound healing. Biomater Med Appl. 2018;2:2.

199. Kim JI, Kim JY, Park CH. Fabrication of transparent hemispherical 3D nanofibrous scaffolds with radially aligned patterns via a novel electrospinning method. Sci Rep. 2018;8:3424.

200. Miyashita H, Shimmura S, Kobayashi H, Taguchi T, AsanoKato N, Uchino Y, et al. Collagen-immobilized poly(vinyl alcohol) as an artificial cornea scaffold that supports a stratified corneal epithelium. J Biomed Mater Res B Appl Biomater. 2006;76:56-63.

201. Wu Z, Kong B, Liu R, Sun W, Mi S. Engineering of corneal tissue through an aligned PVA/collagen composite nanofibrous electrospun scaffold. Nanomaterials (Basel). 2018;8:124.

202. Rafat M, Li F, Fagerholm P, Lagali NS, Watsky MA, Munger R, et al. PEG-stabilized carbodiimide crosslinked collagen-chitosan hydrogels for corneal tissue engineering. Biomaterials. 2008;29:3960-72.

203. Kadakia A, Keskar V, Titushkin I, Djalilian A, Gemeinhart RA, Cho M. Hybrid superporous scaffolds: an application for cornea tissue engineering. Crit Rev Biomed Eng. 2008;36:441-71.

204. Jangamreddy JR, Haagdorens MKC, Islam M, Lewis P, Samanta A, Fagerholm P, et al. Short peptide analogs as alternatives to collagen in pro-regenerative corneal implants. Acta Biomater. 2018;69:120-30.

205. Uchino Y, Shimmura S, Miyashita H, Taguchi T, Kobayashi H, Shimazaki J, et al. Amniotic-immobilized poly(vinyl alcohol) as an artificial cornea scaffold that supports a stratified corneal epithelium. J Biomed Mater Res B Appl Biomater. 2007;81:201-6 
206. Seyed MA, Vijayaraghava K. Physicochemical characterization and bioactivity of an improved chitosan scaffold cross-linked with polyvinyl alcohol for corneal tissue engineering applications. Annu Res Rev Biol. 2018. https://doi.org/10.9734/ARRB/ 2018/39648.

207. Ozcelik B, Brown KD, Blencowe A, Daniell M, Stevens GW, Qiao GG. Ultrathin chitosan-poly(ethylene glycol) hydrogel films for corneal tissue engineering. Acta Biomater. 2013;9:6594-605.

208. Li Y, Yang Y, Yang L, Zeng Y, Gao X, Xu H. Poly(ethylene glycol)-modified silk fibroin membrane as a carrier for limbal epithelial stem cell transplantation in a rabbit LSCD model. Stem Cell Res Ther. 2017;8:256.

209. Soleimanifar F, Mortazavi Y, Nadry S, Soleimani M. Conjunctiva derived mesenchymal stem cell (CJMSCs) as a potential platform for differentiation into corneal epithelial cells on bioengineered electrospun scaffolds. J Biomed Mater Res A. 2017;105:2703-11.

210. Kong B, Sun W, Chen G, Tang S, Li M, Shao Z, et al. Tissueengineered cornea constructed with compressed collagen and laser-perforated electrospun mat. Sci Rep. 2017;7:1-13.

211. Baradaran-Rafii A, Eslani M, Haq Z, Shirzadeh E, Huvard MJ, Djalilian AR. Current and upcoming therapies for ocular surface chemical njuries. Ocul Surf. 2017;15:48-64.

212. Eslani M, Baradaran-Rafii A, Movahedan A, Djalilian AR. The ocular surface chemical burns. J Ophthalmol. 2014;2014:1-9.
213. Chaurasia SS, Champakalakshmi R, Li A, Poh R, Tan XW, Lakshminarayanan $\mathrm{R}$, et al. Effect of fibrin glue on the biomechanical properties of human Descemet's membrane. PLoS One. 2012;7:e37456.

214. Cui Z, Zeng Q, Liu S, Zhang Y, Zhu D, Guo Y, et al. Cell-laden and orthogonal-multilayer tissue-engineered corneal stroma induced by a mechanical collagen microenvironment and transplantation in a rabbit model. Acta Biomater. 2018;75:183-99.

215. Zhang W, Chen J, Backman LJ, Malm AD, Danielson P. Surface topography and mechanical strain promote keratocyte phenotype and extracellular matrix formation in a biomimetic 3D corneal model. Adv Healthc Mater. 2017. https://doi.org/10.1002/adhm. 201601238.

216. Agorogiannis GI, Alexaki VI, Castana O, Kymionis GD. Topical application of autologous adipose-derived mesenchymal stem cells (MSCs) for persistent sterile corneal epithelial defect. Graefes Arch Clin Exp Ophthalmol. 2012;250:455-7.

217. Saghizadeh M, Kramerov AA, Svendsen CN, Ljubimov AV. Concise review: stem cells for corneal wound healing. Stem Cells. 2017;35:2105-14.

Publisher's Note Springer Nature remains neutral with regard to jurisdictional claims in published maps and institutional affiliations. 